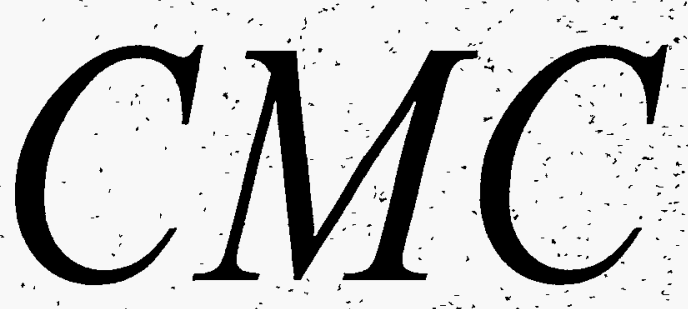

OCCASIONAL PAPERS

RESEIYER

DEC $)$. 1998

OSTI

\title{
Missile Control in South Asia and the Role of Cooperative Monitoring Technology
}

Nazir Kamal.

Security Analyst

Islamabad, Pakistan

Pravin Sawhney

South Asia Correspondent

Jane's International Defense Review 
Issued by Sandia National Laboratories, operated for the United States Department of Energy by Sandia Corporation.

NOTICE: This report was prepared as an account of work sponsored by an agency of the United States Government. Neither the United States Government nor any agency thereof, nor any of their employees, nor any of their contractors, subcontractors or their employees, makes any warranty, express or implied, or assumes any legal liability or responsibility for the accuracy, completeness; or usefulness of any information, apparatus; prodüct, or process disclosed, or represents that its use would not infringe privately owned rights. Beference herein to any specific commercial product process, or service by trade name, trademark manufacturer, or otherwise, does not necessarily constitute or imply its endorsement recommendation, or favoring by the United States Government, any agency thereof or any of their contractors or subcontractors. The views and opinions expressed herein do not necessarily ștate or reflect those of the United States Government, any agency thereof or any of their contractors.

Printed in the United States of America. This report has been reproduced directly from the best available-copy.

Available to DOE and DOE contractors from Office of Scientific and Technical Information PO Box 62

Oak Ridge; TN 37831

Prices available from (615) 576-8401, FTS $626-8401$

Available to the public from

National Technical-Information Service

US Department of Commerce

5285 Port Royal Rd.

Springfield, VA 22161

NTIS price codes

Printed Copy: A03

Microfiche Copy: A01 


\section{DISCLAIMER}

Portions of this document may be illegible in electronic image products. Images are produced from the best available original document. 


\title{
Missile Control in South Asia and the Role of \\ Cooperative Monitoring Technology
}

\author{
Nazir Kamal \\ Security Analyst \\ Islamabad, Pakistan
}

Pravin Sawhney

South Asia Correspondent

Jane's International Defense Review

Cooperative Monitoring Center Occasional Paper/4

\section{(17) Sandia National Laboratories}

Sandia is a multiprogram laboratory operated by Sandia Corporation, a Lockheed Martin Company, for the United States Department of Energy under contract DE-AC04-94AL85000. 
The Cooperative Monitoring Center (CMC) at Sandia National Laboratories assists political and technical experts from around the world to acquire the technology-based tools they need to assess, design, analyze and implement nonproliferation, arms control and other cooperative security measures. As part of its mission, the CMC sponsors research on cooperative security and the role of technology. Reports of that work are provided through the Occasional Papers series. Research is conducted by Sandia staff as well as visiting scholars. The CMC visiting scholars program is administered by the Institute for Public Policy at the University of New Mexico. For additional information on the programs of the $\mathrm{CMC}$, visit the $\mathrm{CMC}$ home page on the World Wide Web at <http://www.cmc.sandia.gov> or write to:

Cooperative Monitoring Center

Sandia National Laboratories

Mail Stop 1373

Albuquerque, NM 87185-1373

For specific information on this report contact:

Kent L. Biringer at the above address.

This report was prepared by Sandia National Laboratories

Albuquerque, NM 87185 and Livermore, CA 94550 


\title{
Missile Control in South Asia and the Role of Cooperative Monitoring Technology
}

\begin{abstract}
The succession of nuclear tests by India and Pakistan in May 1998 has changed the nature of their missile rivalry, which is only one of numerous manifestations of their relationship as hardened adversaries, deeply sensitive to each other's existing and evolving defense capabilities. The political context surrounding this costly rivalry remains unmediated by arms control measures or by any nascent prospect of détente.

As a parallel development, sensible voices in both countries will continue to talk of building mutual confidence through openness to avert accidents, misjudgments, and misinterpretations. To facilitate a future peace process, this paper offers possible suggestions for stabilization that could be applied to India's and Pakistan's missile situation. Appendices include descriptions of existing missile agreements that have contributed to better relations for other countries as well as a list of the cooperative monitoring technologies available to provide information useful in implementing subcontinent missile regimes.
\end{abstract}




\section{Acronyms}

$\begin{array}{ll}\text { ABM } & \text { Anti-Ballistic Missile } \\ \text { BMD } & \text { Ballistic Missiles Defense } \\ \text { BSRBM } & \text { Battlefield Short-Range Ballistic Missile } \\ \text { CBM } & \text { Confidence Building Measure } \\ \text { CCCI } & \text { Command, Control, Communication, and Intelligence } \\ \text { CMC } & \text { Cooperative Monitoring Center } \\ \text { CTBT } & \text { Comprehensive Test Ban Treaty } \\ \text { DGMO } & \text { Director General of Military Operations } \\ \text { DRDO } & \text { Defense Research and Development Organization } \\ \text { EU } & \text { European Union } \\ \text { FMCT } & \text { Fissile Material Cutoff Treaty } \\ \text { GDP } & \text { Gross Domestic Product } \\ \text { GPS } & \text { Global Positioning System } \\ \text { IAEA } & \text { International Atomic Energy Agency } \\ \text { ICBM } & \text { Intercontinental Ballistic Missile } \\ \text { IGMDP } & \text { Integrated Guided Missile Development Programme } \\ \text { INF } & \text { Intermediate-Range Nuclear Forces } \\ \text { IRBM } & \text { Intermediate-Range Ballistic Missile } \\ \text { kt } & \text { kiloton } \\ \text { MIRV } & \text { Multiple, Independently Targetable Reentry Vehicle } \\ \text { MTCR } & \text { Missile Technology Control Regime } \\ \text { NATO } & \text { North Atlantic Treaty Organization } \\ \text { NDC } & \text { National Development Complex } \\ \text { NPT } & \text { Nonproliferation Treaty } \\ \text { NTM } & \text { National Technical Means } \\ \text { PTA } & \text { Pilotless Target Aircraft } \\ \text { RPV } & \text { Remotely Piloted Vehicles } \\ \text { SAR } & \text { Synthetic Aperture Radar } \\ \text { SLBM } & \text { Submarine-Launched Ballistic Missiles } \\ \text { SRBM } & \text { Short-Range Ballistic Missile } \\ \text { SSBN } & \text { Nuclear-Powered, Ballistic Missile Submarine } \\ \text { START } & \text { Strategic Arms Reduction Treaty } \\ \text { TERCOM } & \text { Terrain Contour Matching } \\ \text { UNSCOM } & \text { United Nations Special Commission } \\ & \end{array}$




\section{Contents}

EXECUTIVE SUMMARY . .9

1. INTRODUCTION .................................................................................................................................................11

1.1 NuClear TESTS AND GLOBAL AND REGIONAL PERSPECTIVES...........................................................11

1.2 CONFLICTS BETWEEN INDIA AND PAKISTAN ……..........................................................................11

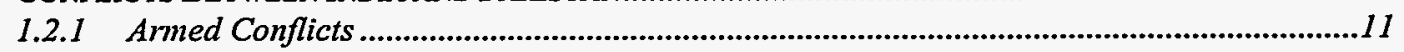

1.2.2 Kashmir Affects Relationship .........................................................................................12

1.2.3 Pakistani Perceptions .........................................................................................................12

1.2.4 Indian Perceptions........................................................................................................12

$1.2 .5 \quad$ Regional Perceptions.......................................................................................................

2. DEVELOPMENT OF STRATEGIC CAPABILITIES ...................................................................13

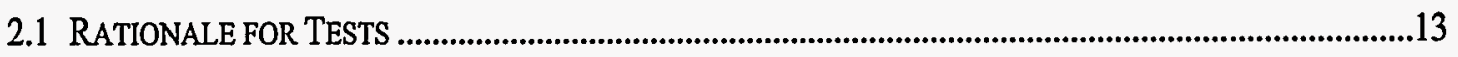

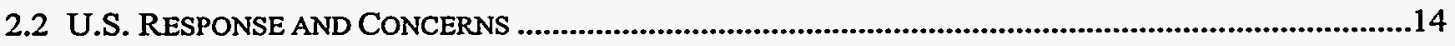

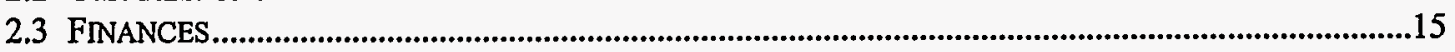

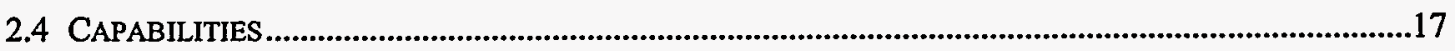

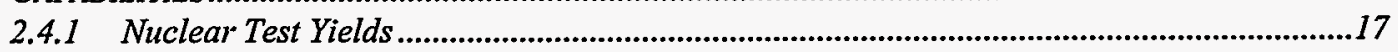

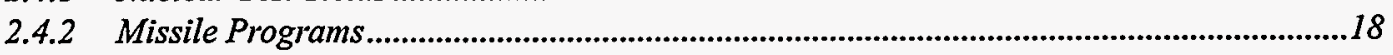

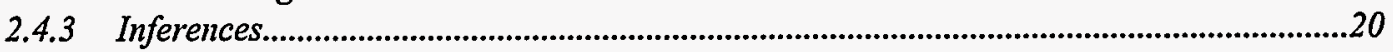

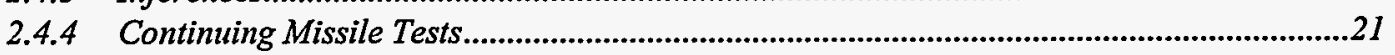

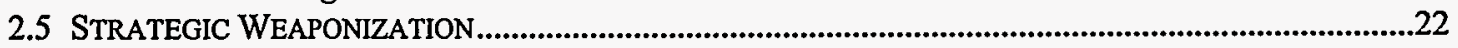

3. MISSILE CONTROL AND COOPERATIVE MONITORING ....................................................22

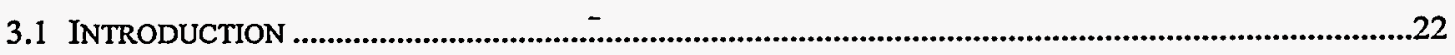

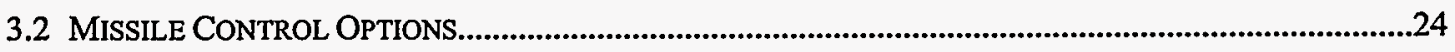

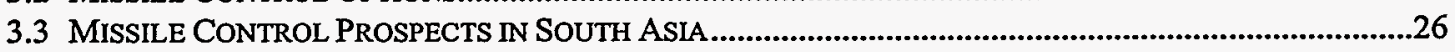

3.3.1 Exercising Mutual Restraint .................................................................................................27

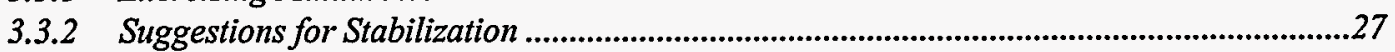

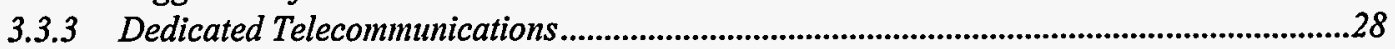

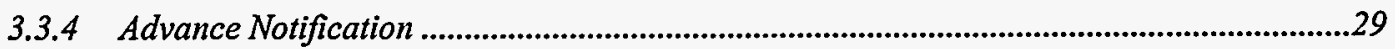

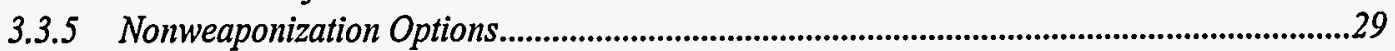

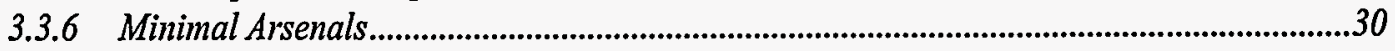

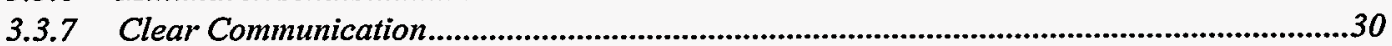

3.3.8 U.S. Interest ..........................................................................................................................

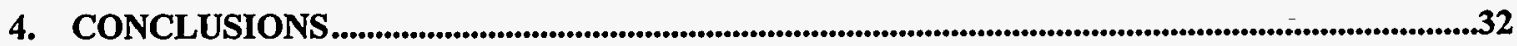

APPENDIX A: MISSILE CAPABILITIES OF INDIA AND PAKISTAN ............................................35

APPENDIX B: MANAGEMENT OF NUCLEAR DETERRENCE ......................................................39

APPENDIX C: SENSORS AND THEIR CAPABILITIES ........................................................................43

APPENDIX D: TYPICAL REQUTREMENTS FOR RESOLUTION (IN METERS) ….......................45

APPENDIX E: EXAMPLES OF COMMERCIAL SATELLITE CHARACTERISTICS ...................47

APPENDIX F: MISSILE CONTROL REGIMES AND COOPERATIVE MONITORING ................49

APPENDIX G: OTHER EXAMPLES OF COOPERATIVE MONITORING AGREEMENTS .......53 
Missile Control in South Asia and

the Role of Cooperative Monitoring Technology

APPENDIX H: TEXT OF HOT-LINE IMPROVEMENT AGREEMENT............................................55

APPENDIX I: ANNEX TO THE HOT-LINE AGREEMENT OF 1971 .........................................................57

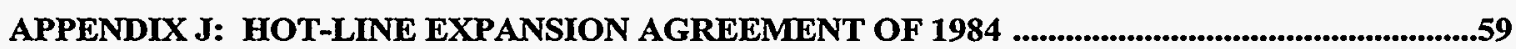

APPENDIX K: MISSILE LAUNCH NOTIFICATION AGREEMENT OF 1988 ................................61

APPENDIX L: AGREEMENT ON NUCLEAR RISK REDUCTION CENTERS .................................63

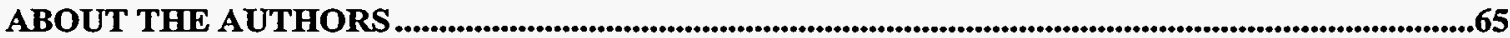

\section{Figures}

FIGURE 1. INTERCONTINENTAL BALLISTIC MISSILE (ICBM) LAUNCH IN INDIA. .............16 FIGURE 2. GHAURI MISSILE LAUNCH, APRIL 6, 1998. (AP WORLDWIDE PHOTO) .............19

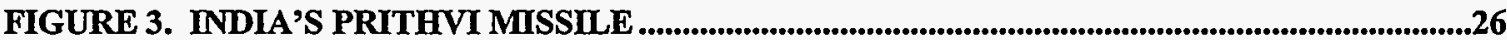

FIGURE 4. PAKISTANI HATF SURFACE-TO-SURFACE MISSILE ...................................................32

Table

TABLE 1. SUMMARY OF INDIA'S AND PAKISTAN'S MISSILE INFRASTRUCTURE................18 


\section{Missile Control in South Asia and the Role of Cooperative Monitoring Technology}

\section{Executive Summary}

India and Pakistan have been engaged in competitive missile development for more than a decade. During this period, there has been little discussion between them about issues of missile control. However, some attention needs to be given to such issues in light of the recent developments in the subcontinent.

The succession of nuclear tests by India and Pakistan in May 1998 has changed the nature of their missile rivalry, which is only one of numerous manifestations of their relationship as hardened adversaries, deeply sensitive to each other's existing and evolving defense capabilities. The political context surrounding this costly rivalry remains unmediated by arms control measures or by any nascent prospect of détente.

In the wake of nuclear tests by India and Pakistan, there is increased risk that at some stage a weaponization of their missile capabilities could occur, even if this does not appear imminent or inevitable at the present time. Their strained relations are prone to escalation of tension and renewed pressures could possibly raise the level of political confrontation in the near or foreseeable future.

Thus, India and Pakistan are faced with the daunting task of establishing strategic stability more urgently than they were during the pre-test period when they maintained a fairly credible and stable nonweaponized equation.

It is encouraging that both sides have shown some appreciation of the task of managing mutual security and stability by referencing the need for restraint and rationality. Both countries seem willing to consider the idea of minimal deterrence.

Despite these positive indications, their intensely adversarial relationship shows little sign of moving towards détente. As a result of unresolved threat-perceptions and disputes between them, mutual distrust and animosity run deep, both at the official and public levels. Their apparently irreconcilable differences over the Kashmir dispute remain the biggest stumbling block to negotiating arms control or other significant securityrelated agreements.

The U.S. has made some encouraging moves toward a constructive engagement with India and Pakistan, notably by offering the prospect of waiving sanctions against them in the event that substantial progress is made towards reducing nuclear tensions and by abandoning its long-standing opposition to the testing and development of missiles. However, the U.S. rejection of minimum nuclear deterrence in the subcontinent conflicts sharply with the security perceptions of India and Pakistan. 
Bilaterally, they may consider ways to reduce missile-related tensions. However, given the nature of existing India-Pakistan relations, only modest suggestions for stabilization measures would seem to hold promise of success in the near term. When the political atmosphere improves, the two countries might consider cooperative monitoring to address sensitive issues of verification and compliance. Both sides should therefore enhance their understanding of cooperative monitoring as it may help to clarify those areas of missile control that they might regard as desirable and feasible.

Until such time, the following measures are proposed:

- A dedicated hot-line communication system linking the heads of government of India and Pakistan. In an emergency they can use this communication link to avert disasters and accidents as well as avoid ambiguous situations that might lead to a strategic crisis.

- Advance notification of any missile launch, which could be modeled either along the lines of the 1971 agreement or the more significant notification agreement of 1988 between the U.S. and former Soviet Union.

- India and Pakistan might seek tacit understandings aimed at keeping their strategic capabilities to the minimum level considered necessary to maintain deterrence as well as refraining from weaponizing their delivery systems.

Hopefully, these proposed measures, if accepted, would serve as building blocks to more significant measures at a later stage when attitudes change or a more propitious political context emerges. 


\section{Missile Control in South Asia and the Role of Cooperative Monitoring Technology}

\section{Introduction}

\subsection{Nuclear Tests and Global and Regional Perspectives}

India conducted a series of five nuclear tests in May 1998 and declared itself a nuclear weapon state. Pakistan followed with a total of six tests. At the global level, these developments were a setback for nonproliferation treaties such as the Nonproliferation Treaty (NPT) ${ }^{1}$ and the Comprehensive Test Ban Treaty (CTBT) ${ }^{2}$, both of which India and Pakistan did not sign. At the regional level, relations between India and Pakistan, and India and China, have worsened. The implications of deteriorating relations between India and Pakistan are immediate, far-reaching, and potentially ominous.

The nuclear tests have changed the nature of the existing missile rivalry between India and Pakistan, which is only one of numerous manifestations of their relationship as hardened adversaries, deeply sensitive to each other's existing and evolving defense capabilities. In order to appreciate the nature of their military competition, it is necessary to examine the political context in which this costly rivalry has been taking place, unmediated by arms control measures or by any nascent prospect of détente.

\subsection{Conflicts Between India and Pakistan}

\subsubsection{Armed Conflicts}

These two adversaries have engaged in three full-blown armed conflicts. In 1948 and 1965, the two engaged in military contests in Kashmir. In 1971, they went to war over India's military intervention in support of an independent Bangladesh (formerly Pakistan's eastern wing).

They also fought a limited armed conflict over the disputed territory of Rann of Kutch, which ended in 1964 through international arbitration. However, a dispute over a portion of their border along Sir Creek (a shifting seasonal stream that drains into the Arabian Sea) has continued. Thus, the demarcation of an agreed border between their territorial waters and exclusive economic zones on the high seas remains unaddressed.

Also, since 1984, India and Pakistan have been engaged in armed conflict over the Siachen Glacier, which has the unpleasant distinction of being the world's highest

\footnotetext{
${ }^{1}$ The NPT recognizes only five nuclear weapon states: the U.S., Russia, UK, France, and China.

${ }^{2}$ The CTBT bans nuclear tests, except sub-critical ones.
} 
Missile Control in South Asia and

the Role of Cooperative Monitoring Technology

battlefield, where far more casualties have been caused by the rigors of climate and terrain than by combat.

\subsubsection{Kashmir Affects Relationship}

Apart from armed conflicts, the long-standing dispute over Kashmir continues to cast the darkest shadow on their relations. While India claims Kashmir to be an integral part of its territory, Pakistan disputes that contention, insisting that the future of that territory be settled through a United Nations supervised referendum that would offer the people of Kashmir the choice of joining either of the two countries. Islamabad has indicated flexibility in the event that negotiations are undertaken to settle the Kashmir dispute. $^{3}$

India and Pakistan differ fundamentally over the nature of the armed unrest in Kashmir, which erupted in the late 1980s and continues unabated. New Delhi has laid much of the blame for that unrest on Pakistan, accusing it of planning the insurgency and infiltrating trained and armed fighters. Islamabad denies that allegation and contends that the insurgency, which seeks to dislodge India, enjoys popular sanction among Kashmir's Muslim majority. India's demand for discussion on Pakistan's alleged support for the militancy in Kashmir and the status of Kashmir on the Pakistani side of the Line of Control has made future talks less likely. Similarly, the visit by a Pakistani cabinet minister to the headquarters of Lashkar-e-Taiba in the Pakistani town of Muridke in April 1998 and his public approbation of this organization's activities does not augur well for progress on the Kashmir issue. ${ }^{4}$

\subsubsection{Pakistani Perceptions}

The dominant perception in Pakistan is that India remains unreconciled to the partition of the subcontinent in 1947 and it is therefore averse to Pakistan's existence as an independent state. Many Pakistanis interpret India's unwillingness to treat Kashmir as a disputed territory, as well as its military intervention that facilitated Bangladesh's independence, as being indicative of an ambition to undermine Pakistan directly or to establish its hegemony in the subcontinent. Among India's South Asian neighbors, Pakistan is the only country that has mounted a military and political challenge to it.

\subsubsection{Indian Perceptions}

On the Indian side, Pakistan is widely seen as a country determined to seize any opportunity to destabilize India internally, including the opportunity to exploit HinduMuslim tensions in India. It is also seen as an overly ambitious country that seeks to achieve military parity with India as well as a coequal political status, regardless of the

\footnotetext{
3 "Navawaz asks India to make major goodwill gesture on Kashmir," The News (Pakistan), August 13, 1998.

${ }^{4}$ The Lashkar is a militant religious group fighting against India in Kashmir and it plans to engage in militant activities in India at large in support of Muslim causes.
} 
unequal size between the two (India is more than six times larger than Pakistan in population and almost as much in territory).

\subsubsection{Regional Perceptions}

It is therefore not surprising that many people on both sides of the Indo-Pakistani divide should exhibit excessive excitement and a renewed sense of bellicosity when there are military-related achievements in their country. A feature of this excitement is the ease with which official pronouncements make their impression on the political elite, if not also on the general public.

Influential groups in both countries espouse military competition and view arms control as an obstacle to such an enterprise. They are critical of arms control or any significant confidence-building measures (CBMs) on the grounds that the other cannot be trusted to abide by the spirit and letter of an accord, or because of an implacable fear that such concepts would or might compromise national security interests. Deep-seated distrust of the other side exists, as well as opposition to any scheme that raises sensitive security questions. In addition, they maintain that unless the overall political relationship normalizes or until disputes of a fundamental nature are settled, arms control must be resisted. A posture of defiance is also a form of pressure on the other side to concede more ground on specific issues. Some factions do not want any restrictions imposed on the military rivalry, being more comfortable playing a zero-sum game in which any gain by the adversary is considered unacceptable because it is perceived as a loss to oneself.

Economic ties between India and Pakistan remain stunted. Trade takes place over a narrow range of goods in contrast to the much larger scale on which indirect and illicit trade occurs between the informal sectors of their economies. Fear of Indian economic domination has helped the hardline elements in Pakistan to stall nascent official efforts to liberalize bilateral trade, which India has advocated. The economic relationship between India and Pakistan is also marked by a high degree of tension.

\section{Development of Strategic Capabilities}

The strategic landscape in South Asia has been changing rapidly in the recent months as a result of nuclear and missile development and testing. This section examines the strategic capabilities of both countries, including the rationale for the tests, status of finances, missiles and nuclear capabilities, and the likelihood of strategic weaponization.

\subsection{Rationale for Tests}

Explaining the rationale for the nuclear tests in May 1998, Indian Prime Minister Atal Bihari Vajpayee, in his letter to U.S. President Bill Clinton, said that there had been a deterioration in the nuclear environment in the region. He referred to China, pointing to its nuclear status and saying that, although there had been some improvement in SinoIndian relations, China was responsible for the 1962 war and their border dispute 
remained unresolved. ${ }^{5}$ Referring obliquely to China and Pakistan, he said that the former had helped the latter to become a covert nuclear weapons state. ${ }^{6}$ Vajpayee accused Pakistan of supporting "terrorism and militancy" in several parts of India, including Kashmir, and blamed it for the three Indo-Pakistan wars.

Avoiding references to past conflicts and other contentious issues, Pakistani Prime Minister Nawaz Sharif said that the earlier Indian tests on May 11 and 13 represented a weaponization of India's nuclear program and this had "led to the collapse of existing deterrence and had radically altered the strategic balance in (the) region." Likewise, the Pakistani army chief, Gen. Jahangir Karamat, presented the Pakistani tests as a "bare minimum response only to re-establish the strategic balance in the region..."

\subsection{U.S. Response and Concerns}

The United States, perceiving the beginning of an arms race in nuclear and missile capabilities in the South Asian subcontinent, sensed an increased risk of a possible nuclear showdown between India and Pakistan over the Kashmir dispute that had been the cause of two wars in the past.

Alarmed, the U.S. quickly embarked on an international strategy to: (1) help reduce tensions over Kashmir by multilateral means, which Pakistan welcomed but which India rejected, insisting on a bilateral approach; (2) urge nuclear stabilization by asking both India and Pakistan to desist from making nuclear weapons, deploying ballistic missiles and conducting further nuclear and missile tests; (3) ask both countries to sign the CTBT and the NPT unconditionally as nonnuclear weapons states; and (4) urge both sides to join future talks on a Fissile Material Cutoff Treaty (FMCT) at the Conference on Disarmament in Geneva.

The primary U.S. concern is that recent developments in South Asia pose a threat to established international arms control and nonproliferation regimes that it has been nurturing for the past three decades. It has been argued that both India and Pakistan lack the finances, the infrastructure, and the doctrines to keep their nuclear capabilities under tight control and to manage their deterrence relationship effectively. The Kashmir issue, the history of mutual enmity and mistrust, and the three wars fought during the last fifty years are reasons enough (in the U.S. view) for the possible outbreak of yet another war and one which could possibly escalate into a nuclear exchange.

\footnotetext{
${ }^{5}$ For the text of Prime Minister Vajpayee's letter to the U.S. President explaining India's reasons for conducting the nuclear tests, see The New York Times, May 13, 1998.

${ }^{6}$ Ibid.

${ }^{7}$ Ibid.

8 “Pakistani's Words: 'To Restore the Strategic Balance,"” New York Times, May 29, 1998.

9 “Pakistan's nuclear tests have corrected the imbalance: Army Chief," PPI (Pakistan Press International) News, June 1, 1998.
} 


\subsection{Finances}

India's annual defense budget is only part of the total allocation for the development of the country's military power. Apart from the Ministry of Defense, three other ministries (dealing with atomic energy, space, and science and technology) would now contribute towards programs for building nuclear weapons and delivery systems. The 1998-99 budget of the new coalition government led by the Bharatiya Janata Party is revealing. ${ }^{10}$ The defense allocation of Rupees 412 billion (US\$9.8 billion) marks an increase of 14.13 percent over the revised estimate of the previous fiscal year, while the finance minister has made assurances that more allocations would be made during the current fiscal year, if needed. Significantly, the allocations are up by 68 percent for the Atomic Energy Commission, 62 percent for the Space Commission, and 58 percent for the Science and Technology Ministry over the previous fiscal year.

The four Indian ministries concerned with the development of nuclear weapons and delivery systems would have closer interaction and interchangeable budgetary allocations. In addition, there would be closer interaction between the Defense Research and Development Organization (DRDO) and various universities. The DRDO has announced the opening of some of its research laboratories to private industry for partnership in research, production, and marketing of military equipment. ${ }^{11}$ The annual military budget supports war preparedness and maintenance of existing conventional capabilities by plugging the operational gaps, while the additional costs for building ballistic missiles may not impose a burden on the Defense Ministry.

Pakistan publishes a brief statement regarding its annual defense budget. India issues a broader statement on its military expenditures, although figures may vary from actual use because allocations may be moved to other services in India's defense budgets. Having a credible nuclear weapons capability places a greater financial burden on Pakistan. With a much bigger economy, India spends about 2.5 percent of its Gross Domestic Product (GDP) on defense, while Pakistan's military spending varies between 6 to 7 percent of its GDP. ${ }^{12}$ Pakistan allocates about 25 percent of its federal government expenditures on defense while the figure for India is around 15 percent. Both sides continue to run large budget deficits ranging from 5 to 6 percent of their GDP.

Under the federal budget for fiscal year 1998-99, Pakistan has allocated Rupees 145 billion (US $\$ 3.2$ billion) ${ }^{13}$ for defense spending, as compared to Rupees 133 billion

\footnotetext{
10 "Defence expenditure to be hiked by 14.13 percent," The Indian Express, June 1, 1998.

11 "DRDO to open laboratories to private sector," The Indian Express, June 18, 1998.

${ }^{12}$ India's GDP is approximately US $\$ 400$ billion, while Pakistan's is approximately US $\$ 70$ billion. These estimates have been extrapolated from The Military Balance 1997-98, International Institute for Strategic Studies, Oxford University Press, London, October 1997.

${ }^{13}$ The conversion has been done at the official exchange rate of Rupees 44 to one U.S. dollar.
} 
Missile Control in South Asia and the Role of Cooperative Monitoring Technology

(US\$3 billion) during the previous fiscal year. ${ }^{14}$ Nominally, this represents an approximate increase of 8.5 percent over the previous fiscal year, but after adjusting for inflation, the increase in real terms is less than one percent. Defense continues to represent about 24 percent of the federal budget, the second highest item in the budget after debt servicing. Defense allocations can be revised upward during the course of the fiscal year, as has been witnessed in both India and Pakistan.

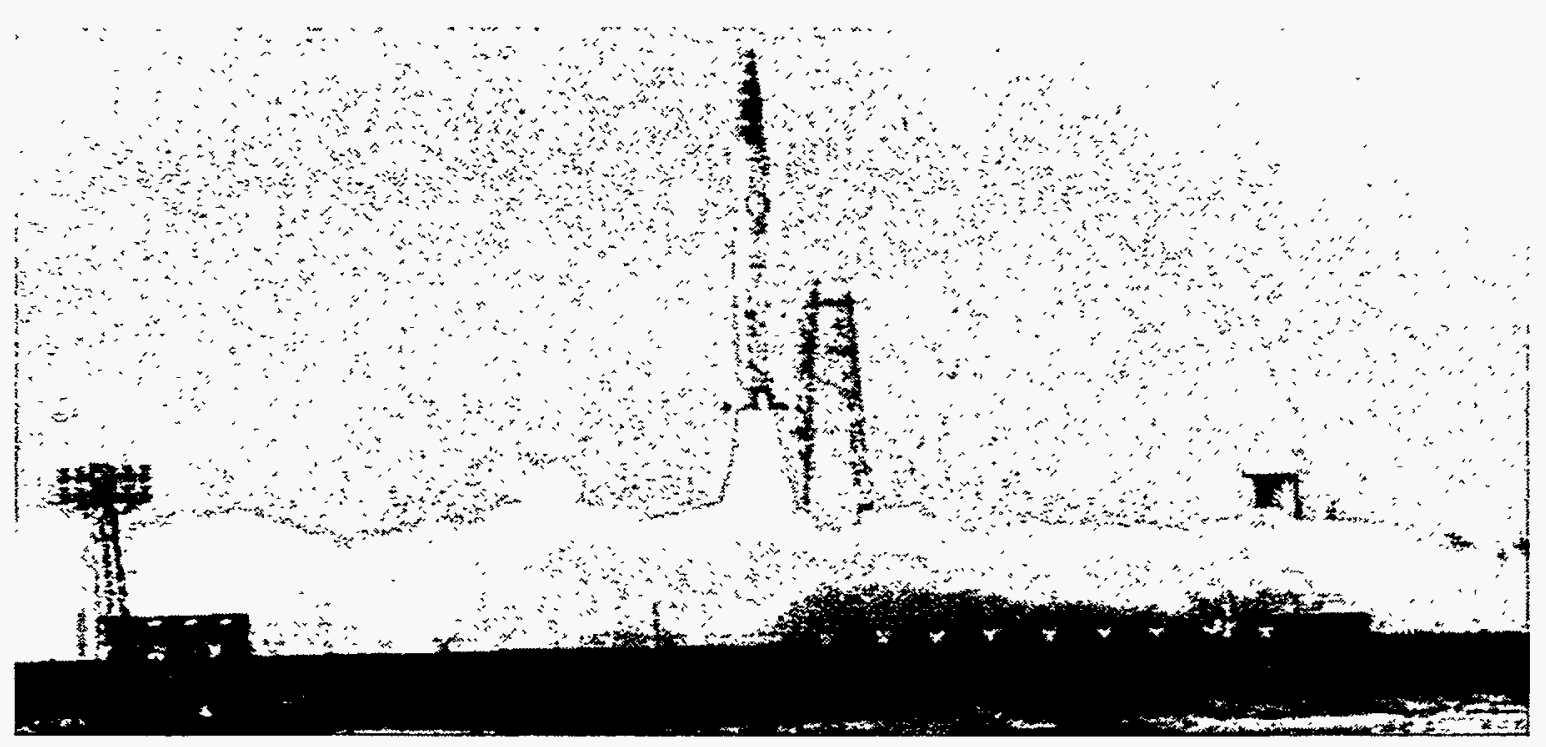

Figure 1. Intercontinental Ballistic Missile (ICBM) Launch in India.

The Agni missiles are India's entrants in the 2,500-km range of missiles. Future developments may range up to $5,000 \mathrm{~km}$, with plans for modular design and solid and liquid fuel. See section 2.4.2 and Appendix A for more information. (Photo courtesy of Jane's International Defense Review.)

${ }^{14}$ See, for example, Dawn, June 13, 1998. 


\subsection{Capabilities}

\subsubsection{Nuclear Test Yields}

India conducted a series of five nuclear tests. The three tests conducted almost simultaneously on May 11 had claimed yields of 0.2 kiloton (kt), 12 to $15 \mathrm{kt}$ (a fission device), ${ }^{15}$ and 43 to $45 \mathrm{kt}$ (a thermonuclear device). ${ }^{16}$ The two tests on May $13 \mathrm{had}$ reported yields of $0.3 \mathrm{kt}$ and $0.5 \mathrm{kt}$. U.S. Department of Defense sources are skeptical of India's claim that one of the nuclear devices was a hydrogen bomb. ${ }^{17}$

Pakistan claimed to have conducted a series of six nuclear tests (five on May 28 and one on May 30). All of the tests were of fission devices. According to one report, of the five tests on May 28, three were reported with yields in the sub-kiloton range, and the remaining two with yields of $25 \mathrm{kt}$ and $14 \mathrm{kt}^{18} \mathrm{Dr}$. A. Q. Khan, however, puts the biggest of the five devices in the range of 30-35 kt, while Dr. Samar Mobarik Mand, who led the test program, claimed that the aggregate yield of the first series of tests was "between 40 to $45 \mathrm{kt."}$ "19 The yield of the test on May 30 was estimated by Dr. Mand at 15 to $18 \mathrm{kt.}^{20}$ According to U.S. Pentagon sources, three of the five devices on the first day did not explode, probably because of design and engineering problems. ${ }^{21}$ But this has been contested by Pakistani scientists involved in the nuclear weapon tests. ${ }^{22}$

Both India and Pakistan have the capability to make free-fall nuclear bombs. India claims to have exploded a thermonuclear bomb, while a leading Pakistani defense scientist says that "it is technically capable of building a thermonuclear device. However, it depends on the Pakistan government's decision to give a go-ahead..23 In reality, it is of little significance whether India or Pakistan has a thermonuclear weapon. The casualties capable of being caused by a fission or a boosted fission bomb would be devastating enough, especially considering that neither side has a credible civil-defense capability while they have large and concentrated population centers.

\footnotetext{
${ }^{\text {Is }}$ This could have been a boosted fission device considering tests involving boosted fission devices may be carried out within this yield range.

${ }^{16}$ Joint press conference by the chairman of the AEC, Dr. R. Chidambaram, and head of the DRDO, Dr. A.P.J. Abdul Kalam. New Delhi, May 17, 1998.

17 "Analysis: experts greet India's H-bomb with suspicion," The New York Times, May 19, 1998.

18 "Some technical information," Dawn, May 28, 1998.

${ }^{19}$ Molly Moore, "'Father of the Islamic Bomb' Defends Role," Washington Post, June 1, 1998, and Sohail Iqbal, "Hydrogen bomb test awaits govt signal," The News (Rawalpindi), June 1, 1998.

${ }^{20}$ Ibid.

${ }^{21}$ MSNBC Pentagon correspondent John King on May 30, 1998.

${ }^{22}$ See, for example, Molly Moore, "Father of the Islamic Bomb," op. cit.

23 "Pakistan capable of building hydrogen bomb," The Nation (internet edition), June 1, 1998.
} 
Missile Control in South Asia and

the Role of Cooperative Monitoring Technology

\subsubsection{Missile Programs}

Both India and Pakistan have been pursuing expansion of their missile programs, seeking missiles with wider ranges and more capabilities. Table 1 summarizes the missile capabilities of both. For more details concerning the individual missile capabilities, refer to Appendix A.

India's Missile Program: Under the indigenous Integrated Guided Missile Development Programme (IGMDP) (begun in 1983), a wide-ranging program was adopted that envisaged the development of a $2500-\mathrm{km}$ Intermediate-Range Ballistic Missile (IRBM) called Agni, a 150-km Prithvi battlefield support missile, two quickreaction, surface-to-air Akash and Trishul missiles, and an anti-tank Nag missile. Modifications were made in the program subsequently for political and operational reasons. For example, Agni was termed as a "technology demonstrator," implying that the political decision to manufacture and integrate this potential IRBM with military forces would be made at a later date. The Prithvi, it was decided, would be made in three variants and Akash was proposed to be modified for an anti-missile role.

\section{Table 1. Summary of India's and Pakistan's Missile Infrastructure}

\begin{tabular}{|c|c|c|c|c|c|}
\hline $\begin{array}{c}\text { Ballistic, Cruise, } \\
\text { \& Anti-missile } \\
\text { Missiles }\end{array}$ & $\begin{array}{c}\text { Payload } \\
\text { (kg) }\end{array}$ & Type & $\begin{array}{c}\text { Maximum } \\
\text { Range } \\
(\mathbf{k m})\end{array}$ & Fuel & Status \\
\hline \multicolumn{6}{|l|}{$I N D I A$} \\
\hline PRITHVI-1 & 1000 & SRBM & 150 & liquid & in service \\
\hline PRTIHVI-2 & 1000 & SRBM & 250 & solid and liquid & development \\
\hline PRITHVI-3 & 500 & SRBM & 350 & solid and liquid & development \\
\hline AGNI-1 & 1000 & IRBM & 2500 & solid and liquid & ready for production \\
\hline AGNI-2 & 1000 & IRBM & 5000 & solid and liquid & development \\
\hline Lakshya (PTA) & 300 & $\begin{array}{l}\text { cruise } \\
\text { missile }\end{array}$ & 500 & & development \\
\hline Akash & - & $\begin{array}{l}\text { anti- } \\
\text { missile }\end{array}$ & 120 & solid & development \\
\hline \multicolumn{6}{|l|}{ PAKISTAN } \\
\hline$\overline{\text { HATF-1 }}$ & 500 & BSRBM & 80 & solid & in service \\
\hline HATF-2 & 500 & SRBM & 300 & solid & development \\
\hline HATF-3 & 500 & SRBM & 600 & solid & development \\
\hline GHAURI (HATF-5) & 700 & IRBM & 1500 & liquid & ready for production \\
\hline GHAZNI & 1000 & IRBM & 2000 & liquid & development \\
\hline SHAHEEN-1 & 1000 & SRBM & 700 & solid & ready for production \\
\hline SHAHEEN-2 & - & IRBM & 2000 & solid & development \\
\hline TARMUK & - & SRBM & 600 & solid & development \\
\hline
\end{tabular}

Data have been collated from various published sources.

All ballistic missiles listed above are nuclear-capable.

BSRBM: Battlefield Short-Range Ballistic Missile

SRBM: Short-Range Ballistic Missile

IRBM: Intermediate-Range Ballistic Missile 
Pakistan's Missile Program: According to General Mirza Aslam Beg, a former Pakistani army chief, Pakistan's missile program was undertaken in early 1987 "on the explicit information gained that India was on the road to pursue its missile development program....it was decided to build missiles of short and medium range capabilities, and also to be equipped with propelled guidance systems."24 (See Table 1 for information on the Hatf family and the Ghauri missiles.) Pakistan's missile program, as disclosed by Dr. A. Q. Khan and also by Dr. Mand, is being undertaken at two research centers: the Khan Research Laboratories (for the Ghauri and perhaps also for Ghazni) and the National Development Complex (NDC). According to Dr. Mand, head of the NDC, his center is developing solid fuel ballistic missiles. A recent Ghauri missile launch is shown in Figure 2.

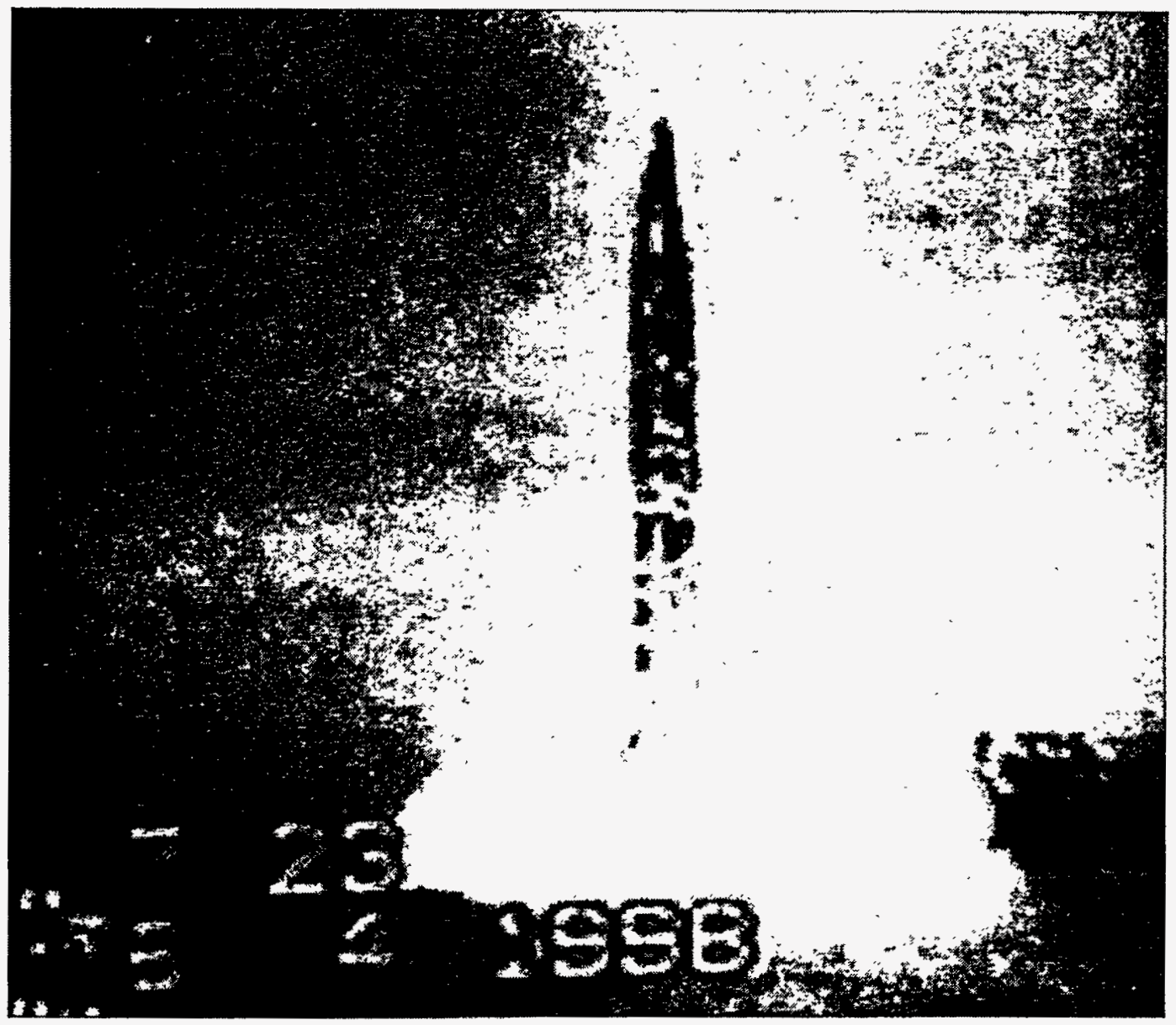

Figure 2. Ghauri Missile Launch, April 6, 1998. (AP Worldwide Photo)

A Ghauri missile, shown in this photo from Pakistan television, has a range of about $1,500 \mathrm{~km}$ (900 miles).

24 "Ghauri won't rock the region," by General Mirza Aslam Beg, Dawn (internet edition), April 27, 1988. 
Missile Control in South Asia and

the Role of Cooperative Monitoring Technology

\subsubsection{Inferences}

The following deductions could be drawn from the declared missile capabilities of India and Pakistan: ${ }^{25}$

1. Agni Ehancements: India's Agni is proposed to have variants with increased ranges up to a maximum of $5000 \mathrm{~km}$ with both liquid and solid propellants. A modular construction would demonstrate its sophistication, easy preparation and combat readiness. Dr. V. K. Saraswat, head of the Prithvi project, stated that India has no plans to develop intercontinental missiles. ${ }^{26}$ The Agni variant tests are expected late in 1998.

2. Missile Mobility: An important feature of Pakistan's Ghauri, Ghazni, Shaheen, and Tarmuk missiles is that all missiles are mobile and hence would retain operational flexibility and surprise. This would make the task of an adversary's anti-missile systems difficult.

3. Battlefield Performance: India's Prithvi missile and Pakistan's Hatf-II have similar capabilities for battlefield performance. Both missiles can be manufactured indigenously. Pakistan also has Hatf-1 guided rockets, and is believed by some countries to have acquired a few M-11 missiles from China.

4. Anti-missile Missiles: India is working on an anti-missile missile (Akash) that is capable of intercepting up to medium-range missiles in the terminal phase. The efficacy of the system would depend greatly on the quality and timeliness of early warning and cueing of the system to engage incoming missiles.

5. Early Warning and Counter-ballistic Missiles Defense: While unmanned aerial vehicles and early warning aircraft may serve the purpose, the real core of early warning is likely to remain based on satellite systems. India plans to send dedicated satellites for the purpose in low earth orbit, but the cost of the satellite in view of its early decay would be a financial strain. The issue has not received the required urgency because China does not have a satellite-based early warning capability at present. The most attractive counter-ballistic missiles defense (BMD) steps in the short term would be those that could saturate and increase chances of defense penetration by ballistic missiles. This makes nuclear warheads more attractive. Other improvements could be an increase in yield-to-weight ratio of warheads, improving multiple re-entry vehicles, and more accurate survivable delivery systems. Building long-range cruise missiles is an attractive option both against ship-borne BMD and ballistic missile defenses in general. As China is moving ahead to counter the proposed U.S. BMD initiative, India has begun work on anti-missile missile systems and on improving satellite-based warning systems. Thus, Pakistan would have to soon consider India's growing capability.

\footnotetext{
${ }^{25}$ See Appendix A for the missile capabilities of India and Pakistan.

${ }^{26}$ Disclosed by the director of Prithvi program, Dr. V.K. Saraswat, The Times of India, April 22, 1998.
} 
6. Cruise Missile Development: Cruise missiles with ranges up to $500 \mathrm{~km}$ and carrying any type of warhead are understood to be under development in India. Research and engineering efforts to fabricate turbofans and micro electronics to make accurate, long-range, strategic cruise missiles is under way. This would be a lengthy process, but the many advantages of cruise missiles (relatively cheap, very accurate, and very difficult to detect and shoot down) make them a better weapon system than ballistic missiles. Apparently, Pakistan has yet to embark on research in this area.

7. Long-range Missiles: India is not likely to plan building either an ICBM or a submarine-launched ballistic missile (SLBM) within the next five years. The Sagarika ${ }^{27}$ missile does not appear to be an SLBM but an anti-ship cruise missile. The Indian government appears to believe that such investments in research and missile doctrine development go beyond its deterrence needs. Unlike the other big powers, India has built its nuclear deterrence for regional security and, at least thus far, not for global geostrategic purposes. The most likely route would be to have multiple nuclear warheads on the extended Agni missile. The technical capability to make low-weight, high-yield nuclear warheads has been confirmed by Dr. R. Chidambaram, Chairman of India's Atomic Energy Commission. "India can produce a nuclear bomb of $200 \mathrm{kt}$ yield after the hydrogen bomb test in Pokharan," he contended. ${ }^{28}$

8. Nuclear Warheads: Statements by some Pakistani nuclear scientists would suggest that Pakistan has a lead over India in making nuclear warheads for ballistic missiles. India is expected to make a decision of making nuclear warheads after the country's first Strategic Defense Review assesses threats and determines the need for and numbers of warheads. No statement has been made by India as to how quickly it can make nuclear warheads. On the other hand, Dr. A. Q. Khan has said that "Pakistan could fit its missiles with nuclear warheads within a matter of days.".29

\subsubsection{Continuing Missile Tests}

India and Pakistan have indicated that missile testing will not stop because they have yet to develop adequately their delivery systems for strategic purposes. The Indian government has declared in the Parliament that the Agni program has entered the next development phase of extending its range and making it a state-of-the-art strategic delivery system. As no weapon system can be perfected without an adequate number of test firings, let alone have the desired level of assurance to enter production, it is implicit that the Agni will have development tests. Pakistan's foreign minister Gohar Ayub Khan

\footnotetext{
27 “After Ghauri, it's over to sea-based Sagarika," The Indian Express, April 28, 1998.

28 "Want real nukes?" The Outlook (internet edition), May 26, 1998.

29 "Pakistan could make nuclear warheads within days," BBC News, June 2, 1998.
} 
Missile Control in South Asia and

the Role of Cooperative Monitoring Technology

has said unequivocally that Pakistan "will continue its missile program..."30 as is evident from the disclosures made by Dr. Mand, head of NDC, about this center's programs.

\subsection{Strategic Weaponization}

After the nuclear tests were conducted in May 1998, there was pressure from some quarters in both India and Pakistan for weaponization of their delivery systems. However, the general view in the region is that this has not occurred. This is also the view currently held by the United States. ${ }^{31}$ It is encouraging that both governments have made statements indicating restraint. However, if weaponization does occur, India is expected to commence low-order nuclear weaponization. Pakistan can be expected to respond tit-for-tat, as it did with the nuclear tests. But the Pakistani focus is less likely to be on building new weapon systems than on enhancing achieved capabilities.

The conversion of capabilities into weapon systems would depend on evolving perceptions of threat to their national security. Investments on research, development, and testing would rise. A pronounced tendency by both sides to make vaunted statements about their capabilities may persist, if only to deter the adversary by forcing it to contemplate worst-case scenarios.

Nuclear arms visibility would enhance the importance of ballistic and cruise missiles as delivery systems. A subcontinental nuclear strategy comprised of a declaratory policy, an employment policy, a deployment policy, and a weapon delivery systems capability would emerge which might bring some stability to the changed situation. While it is difficult to "guesstimate" the nuclear strategy of either country, a listing of considerations that would influence its evolution is possible. (See Appendix B for a discussion of nuclear strategy.) For deterrence and operational considerations, Pakistan would also endeavor to match India's delivery systems in terms of range and payload capability, if not the level of technology.

\section{Missile Control and Cooperative Monitoring}

\subsection{Introduction}

Political will is a major prerequisite for agreements on arms control and other security-related measures. Such agreements can help to reduce tension and even stabilize a security situation between two or more parties. In many cases, they may also require cooperative monitoring, particularly between countries that are deeply suspicious of each other and have a long history of mutual hostility.

\footnotetext{
30 "Pakistan to continue missile plans: Gohar Ayub," The Times of India, April 29, 1998.

${ }^{31}$ U.S. Secretary of State Madeleine Albright stated, "India and Pakistan are somewhere now between having a capability and deployment. We don't want this to move any further." "U.S. hints at security for 'no nukes' pledge," The Straits Times, Singapore.
} 
Neither arms control nor substantive confidence-building measures have figured prominently as concepts that could help to improve mutual security between India and Pakistan. At best these two adversaries have displayed a nominal interest in such security approaches, though there has been more interest in arms control in recent years outside of officialdom, especially among academics. If discussions on arms control issues have taken place between India and Pakistan, these have been very generalized and often a product of mutual posturing.

Some CBMs are in place between India and Pakistan; however, these measures have not contributed much to an easing of tensions in the India-Pakistan relationship. ${ }^{32}$ As in the past, mutual perceptions of threat remain acute, having registered a sharp increase recently as a result of nuclear device and missile tests conducted by them and also because of the accompanying rhetoric of bellicosity and of psychological oneupmanship.

When the dust raised by these major developments settles and the emotions stoked by those developments begin to subside, both sides will be better able to take a hard look at the new complications in their security equation and the challenges of establishing strategic stability. The political context would, however, pose problems in view of their legacy of conflicts, their unresolved disputes, and sensitivities about national security.

Yet, the need for military stability is compelling, especially in the wake of recent nuclear and missile developments. Hopefully sooner than later, the exigencies of mutual security would engender a more positive attitude towards stabilization measures. There are some encouraging signs of that. ${ }^{33}$ When such trends crystallize on both sides, cooperative monitoring could have an important role to play.

No current arms control, security, or confidence-building agreements in South Asia require mutually agreed-upon measures for verifying compliance. However, the concept of cooperative monitoring is now well established at the international level, through various bilateral, multilateral, and global agreements. The concept has been employed for a wide range of purposes, such as military disengagement, confidence

\footnotetext{
${ }^{32}$ In the early 1990s, India and Pakistan agreed on several confidence-building measures: (1) not to attack each other's nuclear facilities and to provide annual updates on the location of those facilities; (2) notification and limitation of military exercises, maneuvers, and troop movements in border areas; (3) prevention of violation of air space by military aircraft and notification of flights along the border; and (4) hotline between the Directorates of Military Operations to defuse tensions that might arise from border incidents. The two agreements relating to land and air forces do not have provisions for on-site observation or any other form of cooperative monitoring.

${ }^{33}$ For example, the Pakistani army chief Gen. Jehangir Karamat said recently: "The new balance in the military equation could lead to restraint and rationality by learning from the painful process the U.S. and former U.S.S.R. (went through) in the Cold War era." NNI (News Network Pakistan), May 31, 1998, titled, "More nuke tests depend on Indian weaponization: Karamat."
} 
Missile Control in South Asia and

the Role of Cooperative Monitoring Technology

building, arms control, and environmental monitoring. See Appendices F and G for examples of these agreements.

\subsection{Missile Control Options}

Ballistic missiles are typically a cause for concern because they possess some distinct characteristics. They have a short flight time between launch and target. Their range can extend from the subregional to the global. They are particularly difficult to defend against and cannot be recalled, nor can their path be changed once they are launched. They are potential delivery platforms for weapons of mass destruction (whether nuclear, biological, or chemical.) Another important feature of ballistic missiles is the difficulty of locating, counting, and assessing them.

A missile control agreement could take various forms. For example, quantity limits could be agreed upon. Either total missiles could be subject to quantity limits or sublimits could be placed on specific missile types. Alternatively, the quantity limit could be placed only on missile warheads. The parties could agree to limits on missile production, leaving out the existing stockpile, or restrictions could be confined to missile testing alone. Another approach could be to place curbs on missile characteristics, that is, on its performance level and physical parameters. Control could also be attempted by putting limits on missile imports and exports. Other potential provisions of a missile control agreement could be limits on the deployment of missiles or on their launch configuration. ${ }^{34}$

Establishing compliance with provisions of a missile agreement may require monitoring of the missile life cycle at various stages. Provisions for a missile agreement could cover a variety of aspects such as research and development, testing, production/procurement, storage/shipping, deployment, retirement, and elimination.

Agreements that involve declarations or are confined to information exchanges would fall in the category of limited transparency. For greater transparency, on-site inspection may prove necessary. On-site inspection could be conducted on a regular basis and/or at short notice by challenge. In order to address the need for additional information, technical instruments may be employed ranging from video systems and ground sensors to aerial over-flights and multi-spectral satellite imagery.

\footnotetext{
${ }^{34}$ One example is the "de-alerting" of nuclear-armed ballistic missiles by removing atomic warheads from them. The idea is to eliminate the hair-trigger situation by delaying the time it would take to launch a nuclear-armed missile. De-alerting could be accomplished by other means as well, for example, by removing the tires of erector launchers and putting blocks on them, or by facing them away from their targets so that they cannot be fired instantaneously. Other examples of de-alerting ideas include giving two orders instead of one for a missile launch before it is carried out; throwing open the safety latch on the launch mechanism of missiles that would require the missile site to be revisited to enable a launch; or removing the integrated circuit boards from missiles and storing them far away from the launch site. The monitoring of such measures would be done by on-site inspection and by other technical means such as the use of ground, airborne, and satellite sensors.
} 
Cooperative monitoring may prove indispensable, especially in those cases where the National Technical Means (NTM) of parties may not be sufficient to monitor compliance. Cooperative monitoring may also prove necessary if the NTM capabilities of negotiating parties are unequal.

Another important role of cooperative monitoring is that, apart from providing robust and flexible means of verification, it can also enhance confidence by itself because of its cooperative nature.

The concept of cooperative monitoring is not, however, aimed at diminishing the role of NTM. It would remain indispensable as an independent source of information both for national reassurance and as a strategic backup to oversee compliance. This would be particularly important between adversaries that have had little or no experience with cooperative monitoring, or are intensely suspicious of each other's motivations and intentions.

Present-day technologies offer a wide range of choices for using the concept of cooperative monitoring to advance arms control and other security/confidence building goals. Most of them are available commercially and have been tested for various applications. ${ }^{35}$ Past experiences with cooperative monitoring can also be used to address distinct issues that might arise in specific geographical and political contexts.

Advances in sensor technologies and the extensive hands-on experience gained with cooperative monitoring can help in designing systems that minimize intrusiveness and reduce financial cost. For example, on-site inspection can be a very tense and exacting exercise, besides being expensive. Minimal intrusiveness could be achieved by relying more on integrated systems of on-site sensors that are linked to remote monitoring stations. Many technologies are relatively simple innovations that can be employed flexibly and in many cases inexpensively.

Any arrangement for cooperative monitoring between highly suspicious adversaries, as between India and Pakistan, would have to be crafted carefully, since flaws could easily lead to misunderstanding or abuse and thereby to a loss of confidence and a worsening of mutual distrust.

\footnotetext{
${ }^{35}$ See Appendix $\mathrm{C}$ for information on sensors with potential for monitoring arms control and other security-related agreements, though they may also have other applications. For technical information on monitoring technologies and their costs, see the Fact Sheets prepared by the Cooperative Monitoring Center, Sandia National Laboratories, Albuquerque, New Mexico. See also Appendix F in Michael Vannoni et al., Confidence Building on the Korean Peninsula, SAND97-0583, op. cit.
} 


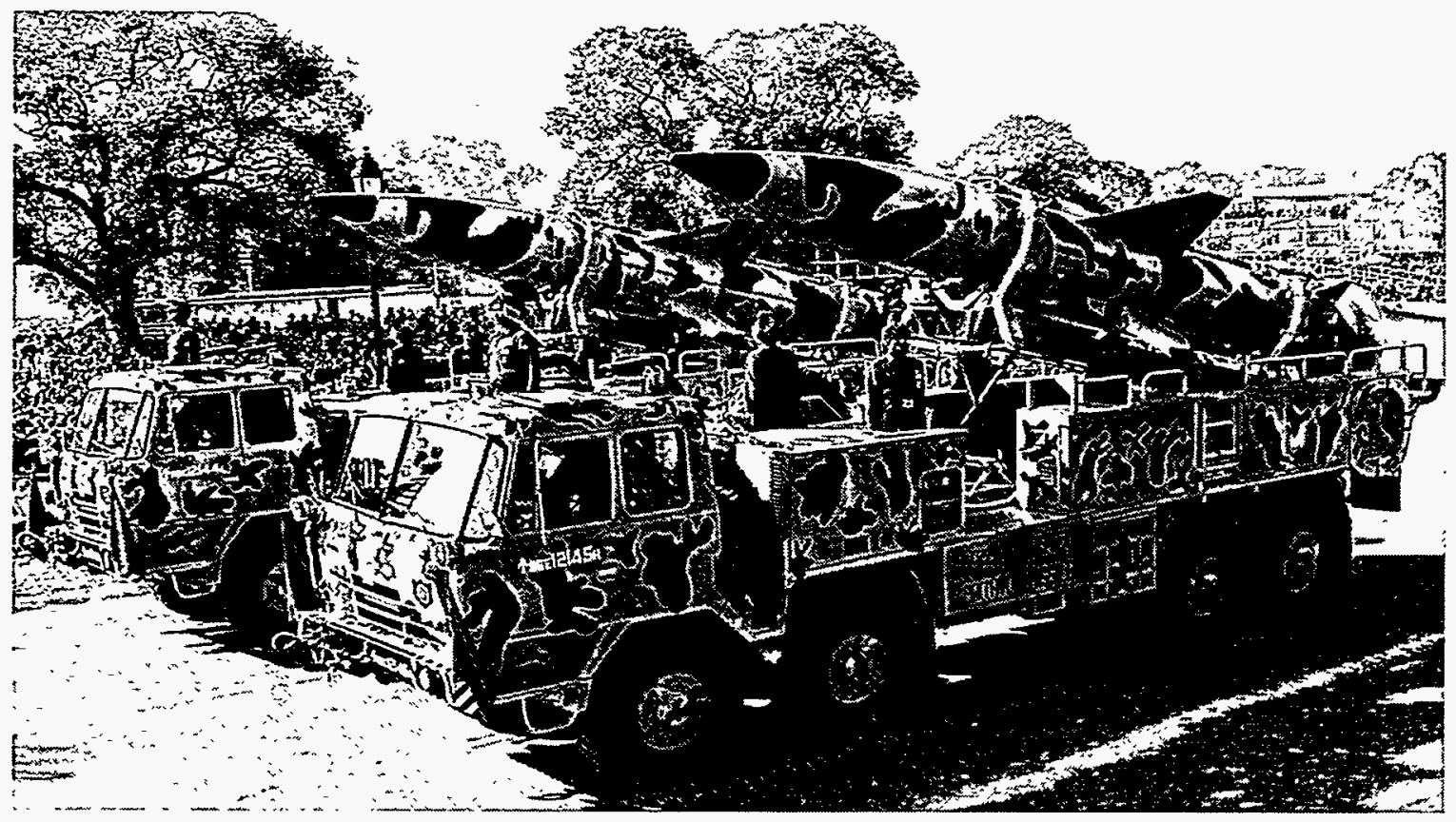

Figure 3. India's Prithvi Missile

The Prithvi family of short-range ballistic missiles has a range from $150 \mathrm{~km}$ for the Prithvi-1 to $350 \mathrm{~km}$ for the Prithvi-3, still under development. (Photo courtesy of Jane's International Defense Review.)

\subsection{Missile Control Prospects in South Asia}

In South Asia, a complete reversal of missile proliferation seems out of the question. India would be opposed to it, as it has been since the outset of the missile issue, while Pakistan's past proposal for a zero-missile regime appears to have lost its importance in the light of recent events, including the development of medium-range missiles.

At any rate, the cooperative monitoring regime that would be required for a zeromissile agreement, as illustrated in missile-related agreements between the U.S. and the former Soviet Union, would be far too intrusive for both sides to accept, especially given their present state of bilateral relations.

In view of their strained relationship (which is prone to escalation of tension), ambitious schemes for missile control would have to give way to limited measures that could contribute to stability while taking account of the deterrence relationship they wish to establish and their sensitivities about national security.

In terms of the missile life cycle, the areas where negotiation of cooperative monitoring agreements could be directed with some prospect of success are missile tests and deployment, together with tacit understandings and other measures to strengthen strategic stability. 


\subsubsection{Exercising Mutual Restraint}

In the immediate aftermath of the nuclear tests, nationalistic utterances by some Indian and Pakistani officials, as well as defense scientists and politicians, raised perceptions that a hair-trigger situation might emerge in the subcontinent. However, the top leadership on both sides have expressed an encouraging commitment to restraint and rationality.

Indian Prime Minister Atal Behari Vajpayee has indicated that his country's nuclear doctrine would be qualitatively different from that of other nuclear powers, and that "we do not need to, or intend to, replicate the kind of command and control structures which they required. Our approach is to have a credible deterrent which should prevent the use of these weapons. ${ }^{936}$

Likewise, at a press conference shortly after Pakistan conducted its first series of tests, Prime Minister Nawaz Sharif offered to resume a dialogue with India on various issues, including peace and security. In that context, he referred to "urgent steps for mutual restraint and equitable measures for nuclear stabilization., ${ }^{, 37}$ Sharif later repeated his reference to nuclear stabilization measures.

Immediately after the nuclear tests carried out by Pakistan, its army chief General Jahangir Karamat said that a new military equation had arisen that could lead to "restraint and rationality" if both sides would heed the lessons of the Cold War between the U.S. and former Soviet Union. Gen. Karamat also suggested that deterrence depended less on the precise numbers of nuclear devices and their yields than on the demonstrated capability to deter the other side. ${ }^{38}$

While these statements create confidence that India and Pakistan would exercise mutual restraint, their overall relationship remains far from normal. As long as their relations remain bogged down by sharp differences over disputes and their intermittent bilateral talks fail to make substantive progress, it will limit the scope for negotiating agreements to establish strategic stability.

\subsubsection{Suggestions for Stabilization}

Nevertheless, the situation arising from the recent nuclear testing and the accelerated development of missile delivery systems underscores the urgency for introducing some measures for stabilizing their strategic equation. Progress made in this direction would also help to contain the additional tensions that nuclear and missile developments have introduced into their bilateral relationship.

\footnotetext{
${ }^{36}$ Kenneth Cooper, "India has a credible deterrent: Vajpayee," The News (Pakistan), June 18, 1998.

${ }^{37}$ Reuters, "Pakistani's Words: To Restore the Strategic Balance," New York Times, May 29, 1998.

38 "Pakistan's nuclear tests have corrected the imbalance: Army Chief," PPI (Pakistan Press International), June 1, 1998.
} 


\section{Missile Control in South Asia and the Role of Cooperative Monitoring Technology}

If deterrence is to work meaningfully and if a certain degree of mutual assurance is to be achieved, it is essential to avoid a hair-trigger situation and, at the very least, engage in unilateral and bilateral efforts to address the risks of miscalculation, accidents, and misunderstandings.

Given the political difficulties discussed earlier, ambitious measures, especially those that may require intrusive cooperative monitoring, are almost certain to prove nonstarters. Thus, suggestions for stabilization would have to be modest.

Yet, even modest measures can impart some stability and, perhaps in time, serve as a valuable building block for a more cooperative system for managing deterrence and strategic stability.

\subsubsection{Dedicated Telecommunications}

There is a compelling need for a dedicated telecommunications system that can provide a prompt, reliable, and direct link between the prime ministers of India and Pakistan in an emergency. There has been a telecommunication link between the Indian and Pakistan heads of government since the late 1980s, but it has not been a dedicated, satellite-based link, nor has it been in place on a continuous basis. Moreover, while in existence, it has reportedly been used intermittently at best. ${ }^{39}$

The proposed dedicated system could be modeled along the lines of the 1971 agreement between the United States and former Soviet Union, which upgraded the hot line between them that was originally established in 1963 following the Cuban missile crisis. $^{40}$

The 1962 missile crisis underscored the urgency of having communication links so that in an emergency or in a fast-changing situation, the heads of government could avert a nuclear exchange that might be caused by a surprise attack or by miscalculation, accidents, and unauthorized actions.

The advances in satellite communications technology offered the prospect of a far more reliable system than the wire telegraphic circuit and the backup radio telegraphic circuit established under the 1963 agreement. These circuits had a single terminal in the U.S. and the former Soviet Union.

39 Southern Asia Policy Brief, Henry Stimson Center, Washington, DC, June 18, 1998. The hotline was first established by Prime Ministers Benazir Bhutto and Rajiv Gandhi in 1989. It was then reestablished in 1990 after changes of government on both sides. Its most recent reinstatement was in 1997. There is also an existing agreement between India and Pakistan dating back to 1990. However, that agreement establishes a communications link between the Directors General of Military Operations (DGMOs) of India and Pakistan and focuses on reducing border tensions, especially along the Line of Control (LoC) in Kashmir. This hotline, which was meant to be used on a routine basis, has scarcely been used, even in moments of crisis.

${ }^{40}$ See Appendices H, I, and J for texts of the 1971 hot-line improvement agreement, the annex to that agreement, and the hotline expansion agreement of 1984, respectively. 


\section{Missile Control in South Asia and \\ the Role of Cooperative Monitoring Technology}

The upgraded system that has been operational since 1978 is based on two satellite communications circuits with multiple terminals in each country, while the original wire telegraphic circuit has been retained as a backup. Each side provides one circuit through its own satellite network.

\subsubsection{Advance Notification}

Another stabilization measure that India and Pakistan might consider is an agreement for the advance notification of missile tests and launches. Again, an example in the area of missile launches could serve as a model.

In May 1988, the Soviet Union accepted a U.S. proposal, offered as a confidencebuilding measure, for an agreement for the advance notification of launches of ICBMs and SLBMs. This agreement provides for the notification, no less than 24 hours in advance, of the planned date, launch area, and area of impact for any launch, and for its transmittal through the Nuclear Risk Reduction Centers that they had already established on a bilateral basis under a 1985 agreement. $^{41}$

The objective of the missile launch notification agreement, besides serving as a CBM, was to reduce the risk of nuclear war, especially as a consequence of misinterpretation, miscalculation, or accident. ${ }^{42}$

The precursor to the 1988 agreement was a more modest accord, signed in 1971, that required each side to provide advance notification of any planned missile launch if such a launch extended beyond its territory and in the direction of the other side.

The act of notifying the other side would in itself constitute a useful confidencebuilding measure.

\subsubsection{Nonweaponization Options}

When India and Pakistan became nuclear-capable more than a decade ago, they maintained these capabilities in a nonweaponized form. Keeping the delivery systems physically removed from their nuclear devices can help to prevent a hair-trigger situation.

In light of the May 1998 nuclear tests, a commitment to nonweaponization could provide much-needed stability during peace time, as political tensions may continue to flare up periodically. It would greatly reduce the risk of accidents as well as lighten the burden on their command and control systems. It would also help to rationalize the role of deterrence in the event of a conventional conflict, especially since conventional deterrence is an important objective of Pakistan's nuclear policy. For example, the act of

\footnotetext{
${ }^{41}$ See Appendix K for the text of the Missile Launch Notification Agreement of 1988, and Appendix L for the text of the agreement on Nuclear Risk Reduction Centers.

${ }^{42}$ A decade later, the U.S. and former Soviet Union went further under the START I treaty that required both sides to provide technical details regarding their missile launch characteristics.
} 
deploying nuclear weapons during the course of a conflict by one side would signal to the other side that the conflict has reached, or is about to reach, a deadly stage, thereby giving the belligerents some time to terminate it, besides spurring outside powers to raise the level of their involvement to defuse the crisis.

There could be political reluctance to enter into an agreement on this and, as far as the near future is concerned, they may also lack the NTM capability to effectively verify such an agreement. But a tacit understanding on nonweaponization may be possible, especially as they have in the past exercised mutual restraint in maintaining a relationship of nonweaponized deterrence - a posture that enjoyed support from a majority of people on both sides.

Ensuring compliance with any tacit understanding, however, may prove difficult, as their NTM capabilities may require additional monitoring and inspection capability as a backup. While India is moving ahead in improving its satellite imagery, and has begun work to develop dedicated military satellites on a priority basis, Pakistan lags far behind, though Dr. A. Q. Khan maintains that Pakistan is capable of moving rapidly toward developing sophisticated satellites. ${ }^{43}$

In any case, until such time as both countries acquire adequate satellite reconnaissance capability, they would have to depend on their NTM, as they did in the past, unless they are prepared to accept assistance from a third country, possibly the U.S., on an informal and discreet basis.

\subsubsection{Minimal Arsenals}

India and Pakistan should also keep their arsenals to the minimum level considered necessary for deterrence. A tacit understanding on this should also be possible, as both sides have made encouraging statements about avoiding the path pursued by other nuclear weapon states. There also seems to be a growing body of opinion in favor of this among nongovernmental people, including some senior retired military officers.

\subsubsection{Clear Communication}

Despite conceptual divergence in their declared deterrence postures, India and Pakistan should be consistent in their declaratory policy and such declarations should be formulated carefully. This is important both to reduce the chances of fundamental misunderstandings and to communicate that policy clearly and credibly. It is essential that the enunciation and reiteration of declaratory policy should be confined strictly to top leadership.

${ }^{43}$ See, for example, M. A. Niazi, "Ghauri dilemmas," The Nation (Pakistan), April 17, 1998. 


\subsubsection{U.S. Interest}

The declared U.S. interest in a constructive engagement with India and Pakistan on nonproliferation issues is an encouraging development. Within two months of the Indian and Pakistani nuclear tests, the U.S. intensified efforts to come to some understanding with both India and Pakistan. At the same time, the U.S. administration obtained authority from Congress to waive the economic sanctions imposed on India and Pakistan for a period of up to 12 months. This is reportedly to be followed by a graduated waiver based on Presidential certification in the event that India and Pakistan were making progress in reducing nuclear tension. ${ }^{44}$

Another significant development was the announcement by U.S. Assistant Secretary of State Karl Inderfurth that the U.S. was "no longer asking India or Pakistan not to test missiles or build more existing types of ballistic missiles or new ballistic missiles; all it now urges is no deployment of ballistic missiles." ${ }^{95} \mathrm{He}$ explained that these long-standing demands were abandoned because they were unrealistic.

The U.S. seeks the unconditional acceptance of the CTBT by India and Pakistan, while remaining opposed to accepting them as nuclear weapon states and rejecting the idea of "minimum nuclear deterrence" between India and Pakistan.

However, the U.S. position conflicts sharply with the security perceptions of India and Pakistan, rendering substantial progress toward regional nuclear stabilization difficult. While India and Pakistan can be expected to discuss, at some stage, ways to reduce nuclear tensions, such a process would be easier to facilitate if the U.S. were to involve itself in it, though this would entail acceptance of the idea of nuclear deterrence in the region.

\footnotetext{
44 "U.S. seeks more flexibility in sanctions on India, Pakistan," The Indian Express, July 14, 1998.

45 "U.S. no longer asking India to end testing or building missiles," The Indian Express, July 16, 1998.
} 


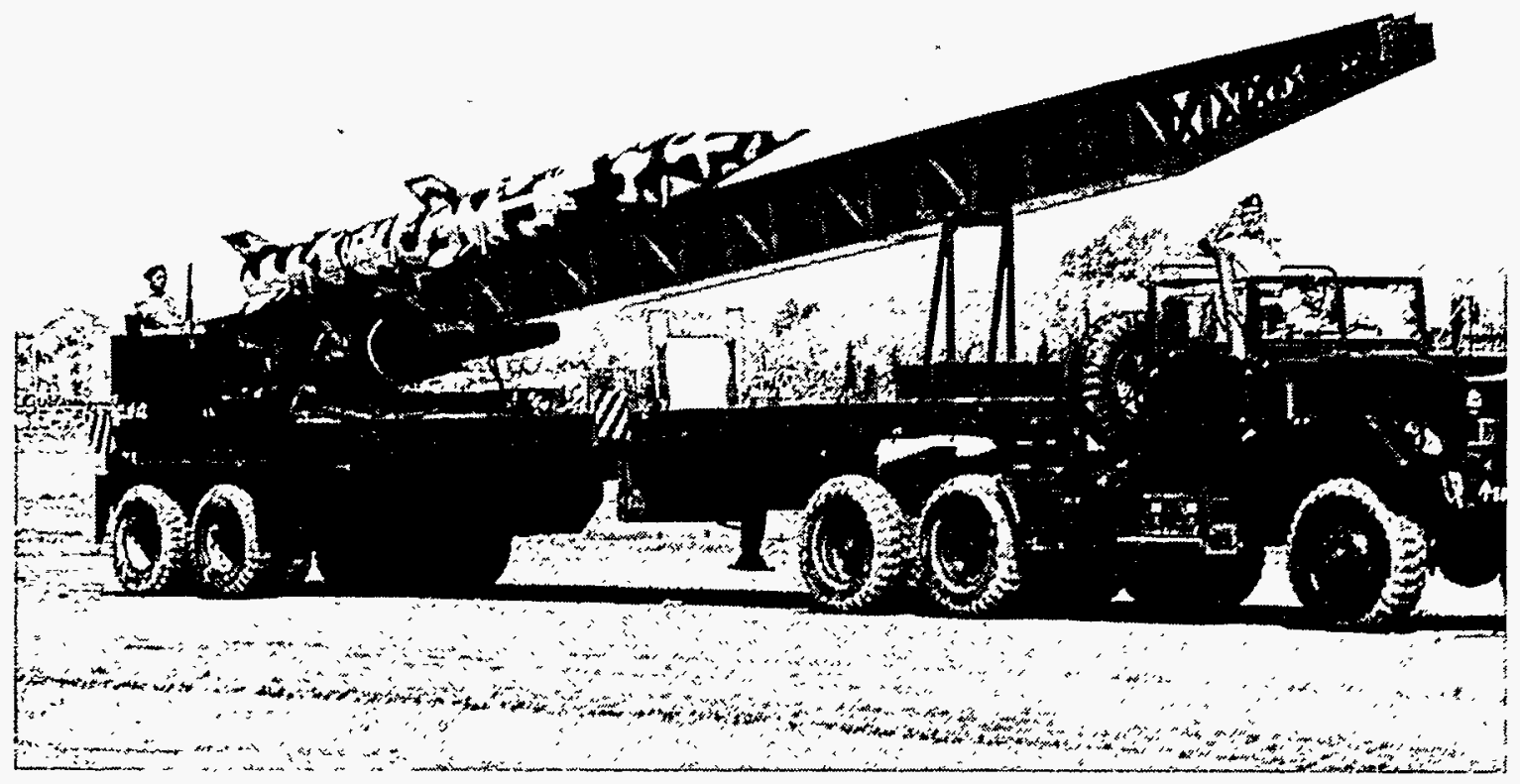

Figure 4. Pakistani Hatf Surface-to-Surface Missile

The Hatf family of Pakistani short-range missiles have ranges from 80 to $600 \mathrm{~km}$, with solid fuel for battlefield or short-range applications. (Photo courtesy of Jane's International Defense Review.)

\section{Conclusions}

In the wake of nuclear tests by India and Pakistan, there is increased risk that at some stage a weaponization of their missile capabilities could occur, even if this does not appear imminent or inevitable at the present time. Their strained relations are prone to escalation of tension and may witness renewed pressures to raise the level of political confrontation in the near or foreseeable future. Thus, India and Pakistan are faced with the task of establishing strategic stability more urgently than they were during the pre-test period when they maintained a fairly credible and stable nonweaponized equation.

It is encouraging that both India and Pakistan have shown some appreciation of the enormity of the task of managing mutual security and stability by making references to the need for restraint and rationality. Both countries might be prepared to consider the idea of minimal deterrence.

Despite these positive indications, the intensely adversarial relationship between India and Pakistan shows little sign of moving towards détente. As a result of unresolved threat perceptions and disputes between them, mutual distrust and animosity run deep, both at the official and public levels. Their apparently irreconcilable differences over the Kashmir dispute remain the biggest stumbling block to negotiating arms control or other significant security-related agreements. Thus, in light of such a political context, only modest suggestions for missile and strategic stabilization measures would seem to hold promise of success in the near term. 
The proposed measures include:

- A dedicated hot-line communication system linking the heads of government of India and Pakistan. In an emergency, they can use this link to avert disasters and accidents as well as avoid ambiguous situations that might lead to a strategic crisis. The very act of establishing such a link would contribute to an easing of tension and mutual apprehensions, at least to some extent.

- Advance notification of any missile launch, which could be modeled either along the lines of the 1971 agreement or the more significant notification agreement of 1988 between the U.S. and former Soviet Union.

- Tacit understandings between India and Pakistan aimed at keeping their strategic capabilities to the minimum level considered necessary to maintain deterrence as well as refraining from weaponizing their delivery systems.

Hopefully, these proposed measures, if accepted, would become the foundation for more significant measures at a later stage when attitudes change or a more propitious political context emerges.

Another suggestion, as an interim measure, is for India and Pakistan to consider making use of a third party's satellite reconnaissance data as a supplement to their own evolving NTM for monitoring the tacit understandings proposed earlier. For political and technological reasons, that third party could be the U.S., assuming that it might be agreeable to the idea. Data obtained from other sources, such as commercial satellite services, could be used as a further backup. Any such international arrangement could be strictly informal and managed discreetly so that it does not impinge on the national sensitivities of India and Pakistan.

Finally, both sides should seek to improve the political context of their relationship so that new areas for more substantive agreements could emerge. In such a situation, cooperative monitoring would have a significant role in addressing issues of verification and compliance, thereby facilitating a more advanced regime of missile control. 
Missile Control in South Asia and

the Role of Cooperative Monitoring Technology

This page intentionally left blank. 


\section{APPENDIX A: Missile Capabilities of India and Pakistan}

This appendix provides more detailed information about India's and Pakistan's missile capabilities.

\section{A-1 India's Missile Program}

A. The Agni46 missile: Agni, which has been flight tested to a maximum range of $1450 \mathrm{~km}$, is planned to be fielded at its advertised range of $2500 \mathrm{~km}$ with a $1000-\mathrm{kg}$ warhead. This missile is ready for production. The government has approved the next phase of Agni envisaging the development of a longer-range system. ${ }^{47}$ According to DRDO chief Dr. A. P. J. Abdul Kalam, the extended-range Agni will have both a solid fuel variant and a liquid fuel configuration. Most important, the new variants of Agni will follow "modular construction."48 The DRDO has announced that different models of the missile would be developed, enhancing the capability up to $5000 \mathrm{~km} .{ }^{49}$ At least six to eight development flights would be required for that purpose.

B. The Prithvi: This missile will be produced in three variants. The first is a battlefield support version, which the Indian army has accepted, with a range of $150 \mathrm{~km}$ and a warhead weight of $1000 \mathrm{~kg}$. The missile is undergoing trickle production. The second Prithvi version for the Indian Air Force is a medium-range missile with a warhead weight of $500 \mathrm{~kg}$ and a range of $250 \mathrm{~km}$. Five successful technical tests of this missile were carried out by April 1997, and it is likely to enter service in 1999. The DRDO has decided to increase the payload of this version from 500 to $1000 \mathrm{~kg}$. The third variant (a trade-off between the range and warhead weight of the mediumrange missile) will have a range of $300 \mathrm{~km}$ for a $500-\mathrm{kg}$ warhead and is planned in both a land and naval version. According to Indian defense minister George Fernandes, the air force version has been successfully flight-tested, while the naval version may need a confirmatory test. ${ }^{50}$

\footnotetext{
${ }^{46} \mathrm{Agni}$ has had three successful test flights (excluding an aborted attempt). The first one was on May 22, 1989, and the last one on February 19, 1994. Officially, until recently, the Agni was a "technology demonstrator" that had demonstrated re-entry phase, accuracy of the guidance system, viability of a solidliquid propulsion system, and the carbon-carbon composite heat shield, achieving a maximum range of $1450 \mathrm{~km}$.

47 "Government approves next phase of Agni," Indian Express, June 4, 1998.

48 "Agni variant to help bridge missile gap," The Hindu, May 18, 1998.

49 The Times of India, April 21, 1998.

50 "Government approves next phase of Agni," Indian Express, June 3, 1998.
} 
C. Other Missiles: The $\mathrm{Akash}^{51}$ and Trishul ${ }^{52}$ missiles are in various stages of development and user trials. The surface-to-air Akash missile for the land forces with a range of $25 \mathrm{~km}$ is undergoing development trials. According to DRDO sources, the Akash thrusting range will be increased to $60 \mathrm{~km}$, and eventually to $120 \mathrm{~km}$. The aim is to modify the Akash to engage missiles as well as aircraft. According to Dr. Kalam, airborne early-warning aircraft to cue the weapon to its expanded role will be acquired. A test bed, based on either a Russian Il-76 or a Boeing 737, is expected to fly in 1999. Extensive testing has already been done with the Avro aircraft (which lacks endurance) as the test bed. Three Akash prototypes are ready. Dr. Kalam is confident that a modified Akash can intercept small missiles traveling at speeds below Mach 3. ${ }^{53}$ In this context, talks with Russia for purchase of eight squadrons of S-300V systems assume significance. The S-300V system uses three phased-array radars with the ability to detect and identify 200 targets at ranges of $250 \mathrm{~km}$. The Trishul is a quick-reaction, (six seconds from detection of target to launch of missile) surface-to-air missile with a 9-km range. After 37 flight trials, the Trishul is ready for user trials by the army. It can engage targets ranging from aircraft flying at up to $500 \mathrm{~m} / \mathrm{s}$ (high level) to $300 \mathrm{~m} / \mathrm{s}$ (low level) as well as hovering helicopters and Remotely Piloted Vehicles (RPVs).

D. Pilotless Target Aircraft (PTA), Lakshya: The indigenous PTA, which was first flown experimentally in 1983, is being converted for combat missions in addition to reconnaissance and use as a target drone. According to Dr. Kalam, India is developing a system that can fly longer, deliver a payload, and come back. The PTA can be converted, without much alteration, to a cruise missile with a range of $500 \mathrm{~km}$ and a $300-\mathrm{kg}$ payload. Efforts continue for an inertial navigation system augmented by either a Terrain Contour Matching (TERCOM) or Global Positioning System (GPS) with an active radar seeker, and an imaging infrared or digital matching correlation terminal guidance system for the PTA.

\footnotetext{
${ }^{51}$ The fire control radar for Akash is a multi-target, multi-function, phased-array radar system called "Rajendra," which has a range of $60 \mathrm{~km}$, a range resolution of $30 \mathrm{~m}$, and can track 20 targets and engage four targets simultaneously.

52 The army version is based on a tracked vehicle and houses all the equipment including the radars, command guidance system, and missiles. The air force version is identical to the army version and differs only in the supporting ground-based platforms. The naval version is a slight variant: it has a sea-skimming capability and serves as a ship-launched, anti-sea-skimmer-missile missile. The naval launcher and the surveillance radar are ready and the fire control system is under final evaluation. All versions after user trials are expected to enter service in the second half of 1999.

53 “Anti-missile role planned for Akash," by Pravin Sawhney, Jane's International Defense Review, January 1997.
} 


\section{A-2 Pakistan's Missile Program}

A. Hatf Missile Development: Giving his version of the development of Pakistan's missile program up to 1991, when he relinquished office as army chief, Gen. Mirza Aslam Beg narrates: "Efforts to improve Hatf-I (range $80 \mathrm{~km}$, warhead weight 500 $\mathrm{kg}$ ) continued and Hatf-II, with a range of $250 \mathrm{~km}$ and a payload of $500 \mathrm{~kg}$, was produced in 1989. This was a free-flight rocket, with an inertial guidance system....Hatf-III was a major breakthrough, which had a $600-\mathrm{km}$ range and a payload of $500 \mathrm{~kg}$, and a proper terminal guidance system, with an accuracy of 0.1 percent, as the circular error probability, at $600 \mathrm{~km}$. The main features of this missile were that it was a two-stage rocket with a warhead separation, a terminal guidance system, and five different varieties of warheads. The most difficult part of the missile was its guidance system, which was developed with the help of Pakistani engineers and scientists working in Pakistan and abroad." ${ }^{.54}$ After a hiatus, Pakistan's efforts led to an official announcement on July $3,1997,{ }^{55}$ that it had tested an 800-km-range missile which was called Hatf-III. It was not explained whether this was the same missile which Gen. Beg had said was ready in 1991.

B. Ghauri Development: Pakistan test-fired its first long-range ballistic missile called Ghauri or Hatf- $\mathrm{V}^{56}$ on April 6, 1998. The 1500-km-range, liquid-fueled missile was developed by the Khan Research Laboratories in Islamabad. According to Pakistan's leading defense scientist, Dr. A. Q. Khan, "Ghauri is much more sophisticated, accurate, and reliable than India's Agni.....the mass production of the long-range Ghauri missile has begun at Kahuta laboratories. ${ }^{957}$ These missiles are expected to be armed with nuclear warheads for deterrence purposes, as indicated by Dr. Khan, who said: "After little adjustment, they (nuclear devices) can be turned into warheads for mounting on aircraft or missiles." its missiles with nuclear warheads within a matter of days., ${ }^{959} \mathrm{He}$ also disclosed that Pakistan "is working on the Ghazni medium-range missile, which will have a range of $2000 \mathrm{~km} .{ }^{360}$ This was also claimed by Pakistan's foreign minister, Gohar Ayub Khan, who said, "The range of the Ghauri missile, capable of traveling $1500 \mathrm{~km}$, could be further extended." Probably the Ghazni will be a variant of Ghauri.

C. Shaheen (Eagle)-I and -II missiles. According to a leading Pakistani nuclear scientist, Dr. Mobarik Mand, this 700-km-range solid fuel ballistic missile, which is

\footnotetext{
${ }^{54}$ Ibid.

55 "Pak tests medium range missile," The Hindu, February 10, 1998.

56 "Pakistan test fires $1500 \mathrm{~km}$ range missile," The Hindu, April 6, 1998.

57 "Mass-scale production of Ghauri begins," Faraz Hashmi, Dawn, June 1, 1998.

58 "Pak devices can be turned into warheads," The Hindu, May 30, 1998.

59 "Pakistan could make nuclear warheads within days," Dr. A. Q. Khan quoted in the BBC news (internet edition), May 31, 1998.

60 "Pak working on $2000 \mathrm{~km}$ range missile," The Hindu, April 16, 1998.
} 
capable of carrying a nuclear warhead, "is already under production. (Its) control and guidance system has been ground tested and (the missile) can travel $700 \mathrm{~km}$ in seven minutes (and it) can hit the target with a precision of $250 \mathrm{~m} . " 161$ Another missile with a range of $2000 \mathrm{~km}$, called Shaheen-II, says Dr. Mand, is "also under production." Shaheen-I "can be tested at an hour's notice, while Shaheen-II would be ready for flight test within a year.".62

D. Tarmuk: There appears to be yet another missile, called Tarmuk. According to one report, this nuclear-capable missile, which has a range of 250 miles, is being prepared for test firing. ${ }^{63}$

\footnotetext{
61 "Shaheen missile awaits go-ahead for test-fire," by Khalid Qayum, The Nation (internet edition), June 1, 1998.

${ }^{62}$ Ibid.

63 "Pakistan ready to test-fire Ghauri, Tarmuk: CIA," The Times of India, June 1, 1998.
} 


\section{APPENDIX B: Management of Nuclear Deterrence}

\section{B-1. Nuclear Strategy}

Nuclear strategy and doctrine take time to evolve. The U.S. and the Soviet Union took years to evolve their doctrines after they had acquired nuclear weapons. Thereafter, the process of refining the doctrines commenced with the changing nature of threats. After four decades of nuclear war planning, it was finally declared by the U.S. and the Soviet Union in 1989 that a nuclear war cannot be won, hence, should not be fought. A significant change came in 1997, under the U.S. Presidential Decision Directive No. 60 (PDD-60), when the U.S. reportedly concluded that it needed nuclear weapons for deterrence purposes only, though its policy of "first use" of nuclear weapons remains in place. ${ }^{64}$

Three important components of a nuclear strategy are a declaratory policy, an employment policy, and a deployment policy.

\section{B-2 Declaratory Policy}

"The military value of nuclear weapons is forever linked to their political value," says a study by a U.S. think tank. ${ }^{65}$ The usefulness of nuclear weapons is generally to deter an adversary from aggressive designs, though in principle it can also be used for offensive objectives, such as a decapitating pre-emptive strike, as mooted by U.S. and former Soviet strategists during the Cold War. It is therefore essential that statements about one's own capabilities and intentions be communicated clearly to the adversary, so that misunderstandings or miscalculations that could have potentially grave consequences are avoided. This is the first vital element of psychological interaction between adversaries and must be well thought through to avoid contradictions.

In theory, statements that exaggerate capabilities are intended to intimidate the adversary, especially if it lacks the means of verification by strategic surveillance. The danger is that too much hype can become counter-productive: the adversary may not take the claims seriously, which could lead to errors of judgment and accidents. Thus, a nation's declaratory policy is not only the first but also perhaps the most important aspect of its nuclear strategy.

On May 27, 1998, Indian Prime Minister Atal Bihari Vajpayee stated in Parliament that:

\footnotetext{
${ }^{64}$ Spurgeon M. Keeny, Jr., "One Step Forward," Arms Control Today (Journal of the American Arms Control Association), November 1997.

65 "Can the nuclear world be changed?" School of Advanced International Studies (SAIS) papers No. 13, page 65, Westview Press, 1986.
} 
Missile Control in South Asia and

the Role of Cooperative Monitoring Technology

"We do not intend to use these (nuclear) weapons for aggression or for mounting threats against any country. These are weapons of self-defense, to ensure that India is not subjected to nuclear threats or coercion. We do not intend to engage in an arms race." An examination of this policy statement suggests that: a) nuclear weapons will not be a part of war-fighting, b) a "no first use" strategy of nuclear weapons would be adopted, c) only a minimum number of nuclear weapons is likely to be produced, and d) putting nuclear forces on a high alert status is not implicit.

In a news conference on May 29, 1998, Pakistani Prime Minister Nawaz Sharif's said that:

"These (nuclear) weapons are to deter aggression, be it nuclear or conventional. ....(India's nuclear testing) has led to the collapse of existing deterrence and radically altered the strategic balance in our region." ${ }^{366}$ A similar statement was also made by Gen. Jahangir Karamat, the army chief, following the Pakistani nuclear tests. ${ }^{67}$ These statements suggest that: a) nuclear weapons could be a part of war-fighting, b) a "no first use" nuclear strategy is not acceptable, c) a minimum number of nuclear weapons may be kept in a ready state for use, and d) an alert status for nuclear weapons with a good command and control system is implicit.

\section{B-3 Employment Policy}

Employment policy deals with the operational military aspects that would be kept highly classified. It would provide the strategic rationale for the nuclear force structure, the targeting norms, and actual use of nuclear weapons in a conflict. Considering that the declaratory policies of India and Pakistan are dissimilar, the employment policies would have different force structuring and targeting norms. For example, the manpower resources and training required for a possible "first use" nuclear policy would be higher. The gradation of targets such as military concentrations, communication centers, industrial infrastructure, and economic assets would have to be done carefully in order to first hit the conventional standing forces rather than the war-making facilities. The 1988 agreement on "no attack on nuclear facilities" signed between India and Pakistan could therefore become redundant. In the event of an early nuclear attack by Pakistan on India's conventional forces, it is likely to evoke a tit-for-tat response from India, which might lead to an uncontrolled escalation.

Besides creating complications, dissimilar nuclear declaratory policies could also prove to be detrimental to a nuclear stabilization regime. There would be more tension and uncertainty.

\footnotetext{
66 “Pakistani's Words: 'To Restore the Strategic Balance," New York Times, May 29, 1998.

67 "Pakistan's nuclear tests have corrected the imbalance," PPI (Pakistan Press International) News, June 1, 1998.
} 
While the strategic rationale (which includes short- and long-term objectives for the use of nuclear weapons) would change and evolve over time, it is important that tension-reducing steps be taken in the interim. The factors that would provoke a country to have a proactive nuclear policy need to be examined, for example: a) by plugging operational gaps in conventional forces, and b) by confidence-building measures to avert nuclear accidents.

\section{B-4 Deployment Policy}

The next aspect of nuclear strategy relates to the stationing of nuclear weapons in the operational context. ${ }^{68}$ This would depend on each side's capabilities in terms of:

- weapon characteristics,

- the range and accuracy of delivery systems,

- the need for hard counter-force targets (military assets) or soft counter-value targets (like large population centers),

- the adversary's surveillance infrastructure,

- limiting collateral damage,

- retaining the credibility of one's own declaratory policy, and

- taking account of dissimilarities in declaratory policies.

\section{B-5 Command and Control}

Pakistan appears to be clear about the command and control of its nuclear weapons. Following the first series of nuclear tests, Prime Minister Nawaz Sharif said: "We have instituted effective command and control structures." Khan, nuclear weapons are "a very sensitive matter and the system (for their control) cannot be given into the individual hands...the Prime Minister along with the Chiefs of Armed Forces will be one to take a final decision." ${ }^{370}$ Likewise, Dr. Samar Mand has called for the immediate establishment of a command, control, communication, and intelligence $(\mathrm{CCCI})$ system for the prompt decisions and responses in a crisis. ${ }^{71}$

Whatever the precise procedure Pakistan adopts, it will be the elected prime minister's final responsibility to decide on its employment in a conflict, just as it was Prime Minister Nawaz Sharif who mulled over the decision to conduct nuclear tests before finally giving his go-ahead.

\footnotetext{
${ }^{68}$ For details of this aspect, see, for example, Brig. V. K. Nair, Nuclear India, Lancers International, New Delhi.

${ }^{69}$ Prime Minister Nawaz Sharif's news conference on May 29, 1998.

70 "Pakistan capable of building hydrogen bomb," The Nation (internet edition), June 1, 1998.

71 "Dr. Samar for setting up command and control structure," Dawn, June 3, 1998.
} 
The final authority in India to use nuclear weapons would rest with the elected government headed by the prime minister. According to Dr. Kalam, India has "a command and control system in a different form. Now we have to consolidate and establish it." ${ }^{.22}$ It seems clear that the command for using nuclear weapons would remain with the prime minister and his cabinet, while the nuclear targeting policy would be the responsibility of the military: the Chiefs of Staff Committee comprising the three services chiefs in consultation with the Prime Minister.

72 "N-weaponisation is now complete: Kalam," The Times of India, May 18, 1998. 


\section{APPENDIX C: Sensors and Their Capabilities}

\begin{tabular}{|c|c|}
\hline Sensor Category & Description of Capabilities \\
\hline $\begin{array}{l}\text { Infrared Break } \\
\text { Beams }\end{array}$ & $\begin{array}{l}\text { When an intruder crosses the invisible infrared break beam (which can } \\
\text { extend across a distance of } 100 \text { meters), it generates an alarm. } \\
\text { Typically, this type of sensor has been used to protect buildings } \\
\text { against intrusion. The infrared break beam can be employed } \\
\text { conveniently in fixed positions or used in a portable mode. Arrays of } \\
\text { break beams can help identify the nature of intrusion beyond merely } \\
\text { detecting it. }\end{array}$ \\
\hline Weight Sensors & $\begin{array}{l}\text { Detecting the passage of vehicles on roads or other well-defined } \\
\text { locations, such as entrance or exit points, can be achieved through } \\
\text { weight sensors, which can be configured to detect different classes of } \\
\text { vehicles according to their approximate weight. }\end{array}$ \\
\hline Fence Sensors & $\begin{array}{l}\text { Examples are taut-wire fences and fiber optic cables. Taut-wire } \\
\text { fences will issue an alarm if any pressure is detected or if they are cut. } \\
\text { These barbed-wire fence sensors are quite robust in adverse weather } \\
\text { conditions. Since taut-wire fences are relatively expensive, they are } \\
\text { generally used very selectively, mainly around facilities or in areas } \\
\text { that require intensive monitoring. Placing pressure on a buried fiber } \\
\text { optic cable will generate an alarm. }\end{array}$ \\
\hline $\begin{array}{l}\text { Microwave } \\
\text { Sensors }\end{array}$ & $\begin{array}{l}\text { Microwave sensors create a field of energy and any intrusion into its } \\
\text { zone of detection will generate an alarm. The detection zone can } \\
\text { vary, depending on the type of sensors used. Their range can extend } \\
\text { from } 20 \text { meters to } 500 \text { meters, with the width of the energy cone } \\
\text { varying from } 1 \text { to } 12 \text { meters. They have been used over an extensive } \\
\text { period for a variety of security applications. A wide range of such } \\
\text { systems have also been tested for outdoor and indoor applications. }\end{array}$ \\
\hline $\begin{array}{l}\text { Unattended } \\
\text { Ground Sensors }\end{array}$ & $\begin{array}{l}\text { Unattended ground sensors include a wide variety of devices linked to } \\
\text { a receiving station by radio frequency. The receiving station can be } \\
\text { either mobile units in the field or a permanent monitoring station. The } \\
\text { sensors' state of health can also be monitored to confirm that they are } \\
\text { functioning properly. Unattended ground sensors include seismic } \\
\text { detectors, magnetic detectors, passive infrared detectors, infrared } \\
\text { break-beam detectors, and break-wire detectors. }\end{array}$ \\
\hline Video Cameras & $\begin{array}{l}\text { Video cameras can determine the cause of alarm signals emitted by } \\
\text { sensors and they can also document events on a continuous basis or by } \\
\text { time-lapse series that can be adapted to meet specific requirements. } \\
\text { The video images can be transmitted to a remote review station in a } \\
\text { digitized form for continuous, real-time monitoring. }\end{array}$ \\
\hline
\end{tabular}




\begin{tabular}{|c|c|}
\hline Sensor Category & Description of Capabilities \\
\hline Aerial Sensors & $\begin{array}{l}\text { The cooperative monitoring technology for aerial inspection can } \\
\text { consist of one or more sensors, depending on the nature of the } \\
\text { agreement. Thus, the Open Skies Treaty of 1992, which allows } \\
\text { detection of large-scale military movement, has a package of sensors } \\
\text { of defined performance levels. The sensors consist of optical and } \\
\text { video cameras with 30-cm resolution, an infrared line scanner with 50- } \\
\text { m resolution, and a synthetic aperture radar with 3-m resolution. See } \\
\text { Appendix D for details about sensor resolutions generally required for } \\
\text { performing different arms control functions. }\end{array}$ \\
\hline Satellite Sensors & See Appendix E for examples of commercial satellite characteristics. \\
\hline $\begin{array}{l}\text { Infrared Line } \\
\text { Scanner }\end{array}$ & $\begin{array}{l}\text { This passive thermal infrared sensor is useful for night-time } \\
\text { reconnaissance of heat-releasing objects. The data are recorded on a } \\
\text { high-resolution video recorder. This sensor is part of the suite of } \\
\text { sensors for the Open Skies Treaty and has been field-tested } \\
\text { extensively in the context of that treaty. }\end{array}$ \\
\hline $\begin{array}{l}\text { Synthetic } \\
\text { Aperture Radar } \\
\text { (SAR) }\end{array}$ & $\begin{array}{l}\text { By transmitting electromagnetic energy to the target ground area, SAR } \\
\text { is able to obtain high-resolution, two-dimensional images at many } \\
\text { points along the aircraft's flight path. 3-D data can also be generated. } \\
\text { Unlike optical and video cameras, SAR can produce images regardless } \\
\text { of weather conditions or the time of day. Side-looking SARs covering } \\
\text { a limited swathe of territory can further restrict the target ground area } \\
\text { so as to conform to the requirements of an agreement, as in the Open } \\
\text { Skies Treaty. }\end{array}$ \\
\hline Tags & $\begin{array}{l}\text { Tags serve as unique identifiers of treaty-controlled objects. Unique } \\
\text { seals are designed to detect tampering with such objects. }\end{array}$ \\
\hline Data Protection & $\begin{array}{l}\text { Commercially available sensor technologies can have built-in } \\
\text { safeguards to ensure that sensitive information is protected, and that } \\
\text { there is no data substitution at the source or when it is received. } \\
\text { Authentication techniques confirm that the data from a specific sensor } \\
\text { source has not been altered from the time of its transmission to its } \\
\text { arrival at a specific destination. A variety of innovative devices can } \\
\text { be used to determine whether a particular sensor has been interfered } \\
\text { with or whether any sealed item, large or small, has been tampered } \\
\text { with. The system design for an integrated sensor network can provide } \\
\text { assurance against tampering. }\end{array}$ \\
\hline
\end{tabular}

Source: Based on Fact Sheets from the Cooperative Monitoring Center, Sandia National Laboratories, Albuquerque, U.S.A. For more information, see the CMC web site at www.cmc.sandia.gov. 


\section{APPENDIX D: Typical Requirements for Resolution (In Meters)}

\begin{tabular}{|c|c|c|c|c|c|}
\hline Target ${ }^{x}$ & Detection $^{b}$ & 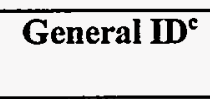 & ${\text { Precise } \text { ID }^{\mathrm{d}}}^{\mathrm{d}}$ & Description $^{\mathrm{e}}$ & $\begin{array}{l}\text { Technical } \\
\text { Analysis } \\
\end{array}$ \\
\hline Bridges & 6 & 4.5 & 1.5 & 1 & 0.3 \\
\hline Supply Dumps & $1.5-3$ & 0.6 & 0.3 & 0.03 & 0.03 \\
\hline $\begin{array}{l}\text { Troop Units (in bivouac } \\
\text { or on road) }\end{array}$ & 6 & 2 & 1.2 & 0.3 & 0.15 \\
\hline Airfield Facilities & 6 & 4.5 & 3 & 0.3 & 0.15 \\
\hline Rockets and Artillery & 1 & 0.6 & 0.15 & 0.05 & 0.045 \\
\hline Aircraft & 4.5 & 1.5 & 1 & 0.15 & 0.045 \\
\hline Surface Ships & $7.5-15$ & 4.5 & 0.6 & 0.3 & 0.045 \\
\hline Vehicles & 1.5 & 0.6 & 0.3 & 0.06 & 0.045 \\
\hline Ports and Harbors & 30 & 15 & 6 & 3 & 0.3 \\
\hline $\begin{array}{l}\text { Coasts and Landing } \\
\text { Beaches }\end{array}$ & $15-30$ & 4.5 & 3 & 1.5 & 0.15 \\
\hline Roads & $6-9$ & 6 & 1.8 & 0.6 & 0.4 \\
\hline Urban Areas & 60 & 30 & 3 & 3 & 0.75 \\
\hline Terrain & --- & 90 & 4.5 & 1.5 & 0.75 \\
\hline \multicolumn{6}{|c|}{$\begin{array}{l}\text { a) Chart indicates minimum resolution in meters at which target can be detected, identified, described, or } \\
\text { analyzed. No source specifies which definition of resolution (pixel-size or white dot) is used, but the } \\
\text { chart is internally consistent. } \\
\text { b) Detection: Location of a class of units, object, or activity of military interest. } \\
\text { c) General Identification: Determination of general target type. } \\
\text { d) Precise Identification: Discrimination within target type of known types. } \\
\text { e) Description: Size/dimension, configuration/layout, components, construction, equipment count, etc. } \\
\text { f) Technical Analysis: Detailed analysis of specific equipment. } \\
\text { Sources: Senate Committee on Commerce, Science and Transportation, NASA Authorization for Fiscal } \\
\text { Year 1978, pp. 1642-1643, and Reconnaissance Hand Book (McDonnell-Douglas Corporation, 1982), } \\
\text { p. } 125 \text {. }\end{array}$} \\
\hline
\end{tabular}

Source: Michael Vannoni et al., Confidence Building on the Korean Peninsula, Appendix F, op. cit. 
Missile Control in South Asia and

the Role of Cooperative Monitoring Technology

This page intentionally left blank. 


\section{APPENDIX E: Examples of Commercial Satellite Characteristics}

Commercial satellites are especially suitable for visually monitoring large areas. Comparing satellite images over time can help detect changes of significant size, such as the construction of roads and missile facilities. The images can range from the optical to other bands on the electromagnetic spectrum.

Significant improvements are under way in the resolution of commercial satellite imagery. An increased network of satellites and their ability to direct the optical systems will shorten the time it will take commercial satellites to revisit previously imaged sites. The cost of satellite images has declined as the commercial satellite business becomes increasingly competitive. The technology has also become more versatile. Future systems will offer 2-m or less resolution, making it possible to distinguish missile launchers from other vehicles. The Indian commercial IRS-series satellites offer the most advanced resolution (about $5 \mathrm{~m}$ ) in current commercial satellite imagery. (Historical 2-m data is available from Russia.) ${ }^{73}$

The resolution of an imaging sensor (whether cameras, infrared scanners or SARs) should serve the stated purpose of an agreement. Thus, depending on the scope of arms control measures or agreements, or CBMs, the resolution of sensors to be employed can vary considerably. The table below lists existing and planned commercial satellite platforms.

\begin{tabular}{|l|l|l|l|l|l|}
\hline \multicolumn{1}{|c|}{ Satellite } & Country & Resolution & \multicolumn{1}{c|}{ Sensitivity } & \multicolumn{1}{c|}{$\begin{array}{c}\text { Revisit } \\
\text { Time }\end{array}$} & \multicolumn{1}{|c|}{ Status } \\
\hline EARLYBIRD & U.S. & $3 \mathrm{~m} / 15 \mathrm{~m}$ & $\begin{array}{l}\text { Black \& white/ } \\
\text { Multispectral }\end{array}$ & $\begin{array}{l}\text { Not yet } \\
\text { operational }\end{array}$ \\
\hline LANDSAT & U.S. & $30 \mathrm{~m}$ & Color (7 bands) & 16 days & Existing \\
\hline SPOT & France & $10 \mathrm{~m} / 20 \mathrm{~m}$ & $\begin{array}{l}\text { Color (3 bands) or } \\
\text { black and white }\end{array}$ & 26 days & Existing \\
\hline KVR-1000 & Russia & $2 \mathrm{~m}$ & Black and white & N/A & Historical \\
\hline ERS-1 & EEC & $8 \mathrm{~m} / 30 \mathrm{~m}$ & Synthetic aperture radar & 35 days & Existing \\
\hline IRS-1C/1D & India & $5 \mathrm{~m} / 20 \mathrm{~m}$ & $\begin{array}{l}\text { Black and white/ } \\
\text { multispectral }\end{array}$ & 24 days & Existing \\
\hline JERS-1 & Japan & $25 \mathrm{~m}$ & 7 bands and radar & 44 days & Existing \\
\hline RADARSAT & Canada & $10-100 \mathrm{~m}$ & Synthetic aperture radar & 24 days & Existing \\
\hline
\end{tabular}

Source: Technology Display Center at the CMC, Sandia National Laboratories, Albuquerque, New Mexico, U.S.A.

\footnotetext{
${ }^{73}$ Commercial satellite imagery will soon become available at an inexpensive price. A consortium of U.S. companies (Aerial Images, Microsoft, Kodak, and Digital Equipment) and a Russian government agency (Sovinformsputnik) banded together this year to put satellite imagery covering virtually the entire planet on the Internet. When the project of mapping is completed next year, using Russian and other satellites with 2 -m resolution cameras, it will result in the world's largest digital atlas. Downloading an image is expected to cost a mere US $\$ 8.50$, while obtaining a poster-size print from Kodak will cost US\$20 to US\$30 each.
} 
Missile Control in South Asia and

the Role of Cooperative Monitoring Technology

This page intentionally left blank. 


\section{APPENDIX F: Missile Control Regimes and Cooperative Monitoring}

\section{F-1 Anti-Ballistic Missile Agreement of 1972}

The earliest example of missile control and monitoring regimes is the AntiBallistic Missile Agreement (ABM) of 1972 between the United States and the former Soviet Union. This agreement confined the areas where interceptor missiles could be deployed to two sites. Each missile launcher was also restricted to a single interceptor missile, with each site limited to a maximum of 100 launchers and interceptors. The $\mathrm{ABM}$ treaty also put restrictions on the development of new anti-missile systems that could be used for strategic defense. For that purpose, it included constraints on the orientation and physical location of early warning radars so that they could not be used in an anti-missile role. For monitoring this complex agreement, the parties rely wholly on their NTM, though the treaty provides for a Standing Consultative Commission to sort out issues of noncompliance. Some allegations of infringement remained unresolved until after the end of the Cold War. The purpose of this treaty was to prevent the acquisition of a strategic shield that might embolden either side to adopt a more offensive nuclear posture or to contemplate a decapitating first strike.

\section{F-2 Advance Notification}

Another type of missile treaty is the agreement between the United States and former Soviet Union in 1988 entailing the notification of launches of intercontinental ballistic missiles (ICBMs) and SLBMs. Its stated purpose is to reduce the risk of nuclear war that might occur as a result of misinterpretation, miscalculation, or accident. The agreement provides for advance notification of the planned date, launch area, and area of impact of any ICBM or SLBM test. This treaty is an improvement on an earlier agreement in 1971 that called for prior notification of any planned missile launches that extended beyond national territory and in the direction of the other party.

\section{F-3 Strategic Arms Reduction Treaty (START I)}

A more significant treaty in force is the 1991 START agreement, which took a decade to conclude. This treaty imposes limits on delivery vehicles (mostly missiles), warheads, and payloads. It stipulates the reduction of strategic weapons by about onethird of the pre-existing level and sets a period of seven years for completing the destruction process, starting from the time of the treaty's ratification in 1994.

START I incorporates one of the most far-reaching monitoring regimes in arms control history, featuring a variety of on-site inspections, continuous monitoring of ICBM assembly plants, special inspections, and other cooperative measures, including the exchange of telemetry data from missile tests and launches as well as data exchange to assist verification by NTM. Disclosures to establish the baseline for inspection required detailed data exchanges and extensive notifications. 
Missile Control in South Asia and

the Role of Cooperative Monitoring Technology

\section{F-4 START II}

Even more significant is the follow-up treaty to START I. Concluded in 1993, START II has yet to come into force because of a delay in ratification by the Russian parliament. Under this treaty, the two sides are to draw down their strategic arsenals (including ballistic missile delivery systems) by a further one-third by the year 2003 . Together, START I and START II would reduce the strategic arsenal by two-thirds of the level existing in 1993. A distinguishing feature of START II, apart from seeking a deeper reduction of the strategic arsenal, is the complete removal of the most destabilizing type of nuclear weapon systems, namely, the MIRVs (Multiple, Independently Targetable Reentry Vehicles) on deployed land-based missiles.

\section{F-5 Monitoring Iraq}

A missile monitoring and control regime is enforced in Iraq. UN Security Council resolutions that ended the Gulf War prohibited Iraq from possessing ballistic missiles with ranges greater than $150 \mathrm{~km}$.

The UN performs on-site inspections of the destruction of prohibited missiles and monitors the testing of missile motors with video cameras, supported by a simple measuring device on the motor platform. The visual data is transmitted to the United Nations Special Commission (UNSCOM) headquarters in Baghdad, where it is accessed on a computer screen by a permanent monitoring staff. Data is also sent to the UN headquarters in New York.

\section{F-6 MTCR}

The Missile Technology Control Regime (MTCR) was established in 1987 at U.S. initiative in the wake of missile warfare between Iraq and Iran. This multilateral regime prohibits the export of ballistic missiles, space launch vehicles, cruise missiles, and other remotely piloted vehicles capable of carrying weapons of mass destruction (defined as having payloads of more than $500 \mathrm{~kg}$ and ranges exceeding $300 \mathrm{~km}$ ). The MTCR also bans the transfer of technology components for such missiles.

Originally MTCR was confined to nuclear weapon delivery systems, but this was enlarged to include chemical and biological weapons in 1992, in the aftermath of the Gulf War. The membership of MTCR has grown to 29 countries, with almost all belonging to the developed world, including Argentina and Brazil, which were previously adversaries engaged in missile development efforts.

MTCR is neither a treaty nor an international agreement. It is a voluntary arrangement under which the parties engage in cooperative efforts at tightening national laws and implementation machinery with regard to missile and related technology exports. This is done through plenary and inter-sessional meetings of the participating countries. 


\section{F-7 INF Treaty}

The most significant arms control agreement that focuses exclusively on missiles is the Intermediate Range Nuclear Forces (INF) Treaty between the United States and the former Soviet Union. In force since 1988, this treaty has eliminated an entire class of missiles-those within the ranges of 500-5500 km. A key provision was the destruction of all such missiles, together with their launchers and support facilities, within a threeyear period. Through June 1991, a total of 2,692 missiles had been destroyed.

The INF contains a comprehensive regime for verification that includes noninterference with each other's NTM, comprehensive on-site inspection (including permanent presence at the entrance of missile production and final assembly facilities), and cooperative display measures, such as the routine opening of the shelter roofs of all strategic mobile launchers to enable the other side to confirm by satellite the absence of INF-prohibited missiles. ${ }^{74}$ The latter practice has now ended.

The parties to the agreement also have the right to carry out a maximum of 10 short-notice inspections of each other's former operating bases and support facilities related to INF-prohibited missiles. A total of more than 160 sites were involved, including more than 35 U.S. sites.

Continuous on-site inspection of portals of designated facilities will end by May 2001. If a facility has ceased activities that require monitoring, the monitoring could be terminated a year after such cessation. Thus, monitoring by Russia of the single U.S. facility in Utah has already ended.

The implementation of the INF treaty posed little problem and proceeded according to schedule. The process of implementation of the agreement began with inspections to confirm the baselines declared by both sides of their prohibited missile inventory, facilities, and sites.

It should be noted that the preliminary negotiations for an INF treaty had made little progress during the first half of the 1980s. At that time, Cold War tensions were at a height following the Soviet military intervention in Afghanistan. But by the time the treaty was concluded, the tension had begun to abate. The reforms under glasnost and perestroika launched by Soviet leader Mikhail Gorbachev had started to change the character of the Soviet communist system, besides introducing a measure of détente into the U.S.-U.S.S.R. relationship.

\section{F-8 Reducing Risk of Accidental Conflict}

The Cold War, however, did not prevent agreements between the U.S. and former Soviet Union aimed at reducing the risk of accidental conflict that involved the sharing of

\footnotetext{
${ }^{74}$ See Clause 3 of Article XII of the INF treaty.
} 
Missile Control in South Asia and

the Role of Cooperative Monitoring Technology

specific information. As mentioned earlier, they signed an agreement in 1971 for the notification of missile launches that was upgraded in 1988.

\section{F-9 Hot-line Agreement of 1963}

Yet another agreement requiring some measure of cooperation was the Hotline Agreement of 1963, which came in the wake of the Cuban missile crisis. Its purpose was to provide direct communication between the American and Soviet leadership so they could avert a nuclear war that might be caused by accidents, ambiguous activities, or by unauthorized actions. This agreement was upgraded in 1971 (see Appendices $\mathrm{H}$ and $\mathrm{I}$ ) and the new system became fully operational in 1978. The agreement was expanded in 1984 (see Appendix J). 


\section{APPENDIX G: Other Examples of Cooperative Monitoring Agreements}

Cooperative monitoring is now well established at the international level, through various bilateral, multilateral, and global agreements. The concept has been employed for a wide range of purposes, such as military disengagement, confidence building, arms control, and environmental monitoring. Some of these diverse agreements are:

- the Sinai disengagement agreement between Egypt and Israel in 1974;

- the Golan Heights disengagement agreement between Israel and Syria in 1974;

- the Egypt-Israel Peace Agreement of 1979 that established force-limitation zones;

- the Intermediate Range Nuclear Forces (INF) Treaty of 1988 between the United States and former Soviet Union that eliminated an entire class of ballistic missiles between the ranges of $500 \mathrm{~km}$ and $5500 \mathrm{~km}$;

- the aerial inspection agreement between Hungary and Romania in 1991 that facilitated a settlement of their long-standing dispute over ethnic minorities;

- the multilateral Open Skies treaty of 1992 between the countries belonging to the North Atlantic Treaty Organization and former Warsaw Pact (which is still awaiting ratification);

- the ABACC agreement between Brazil and Argentina for mutual inspection of nuclear facilities that paved the way for the International Atomic Energy Agency's (IAEA's) role;

- the treaty on Conventional Forces in Europe of 1990 that put limits on various weapon categories and their deployment zones; and

- the two treaties on strategic arms reduction between the United States and Russia (START I and START II).

Examples of environmental cooperative monitoring include the bilateral experiment between the United States and Mexico for checking and alleviating pollution levels along their border, and the more ambitious Black Sea Environment Program established by NATO, UN, IAEA, World Bank, and European Union (EU) in 1993.

Experimental efforts are under way aimed at exploring the prospects of opening up new areas for transparency as a confidence-building measure. Many countries, for example, are engaged in preliminary steps to introduce more openness of nuclear material storage. In this context, attention is focused on remote monitoring to lessen intrusiveness and reduce reliance on on-site inspection. Bilateral experiments are in place between the United States and countries such as Argentina, Sweden, and Australia. 
A more significant experiment between the United States and Russia covered nuclear material storage facilities. In this experiment, highly enriched uranium is being mutually monitored at sites in each country. This exercise is part of a major effort to test the technology and assess the effectiveness of remote monitoring systems for future application.

The U.S. and Australia also carried out a recent experimental project. Using various sensors and remote monitoring, they tracked the shipment and monitored the security of sensitive material shipped from the Australian port of Adelaide all the way to Rotterdam, the Netherlands, across the Pacific and Atlantic oceans.

There are also tentative moves towards using cooperative monitoring technology to enhance mutual trust and confidence in Latin America, where the concept of Open Skies is beginning to take hold. These nascent developments are taking place against a background of sweeping changes in the international environment of that hemisphere together with significant domestic political changes witnessed in recent years, especially in the countries of Chile, Argentina, and Brazil.

Depending on the nature of an agreement and its political context, cooperative monitoring technologies offer numerous options, ranging from regular and short-notice physical inspection of sites to purely technical monitoring by means of on-site sensors or by remote sensing utilizing satellites or aircraft of various capabilities.

There can be considerable variation in the scope and scale of cooperative monitoring. For example, the agreement between Hungary and Romania for aerial inspection by unarmed aircraft involves the use of optical cameras of a specified resolution in contrast to the wider suite of sensors agreed to in the multilateral Open Skies Treaty. ${ }^{75}$

Similarly, the Sinai disengagement accord of 1974 involved more intensive monitoring than the system that was agreed to for monitoring the force-limitation zones established under the subsequent peace agreement of 1979 . Despite the complexity and novelty of the monitoring system developed for Sinai II, the technology was simple and robust. With the help of political will on both sides, it worked smoothly and thereby contributed significantly to the conclusion of the peace agreement as well as the subsequent termination of the Sinai II monitoring system.

In some situations, technology may play a minimal role, as in the Golan Heights where the disengagement zone is monitored by UN personnel without the use of sensors. Despite the absence of a peace agreement between Israel and Syria and the high level of mutual hostility that has existed since the accord was signed, the agreement has worked well because the system provides enough early warning to both sides.

\footnotetext{
${ }^{75}$ While both these agreements permit extensive geographical coverage, in other contexts this can be restricted to specific flight paths and altitude slots. Since aerial inspection is a joint undertaking, there would be assurance against any deviation from agreed parameters.
} 


\title{
APPENDIX H: Text of Hot-Line Improvement Agreement
}

\author{
AGREEMENT BETWEEN THE UNITED STATES OF AMERICA AND THE UNION OF SOVIET SOCIALIST \\ REPUBLICS ON MEASURES TO IMPROVE THE U.S.A.-U.S.S.R. DIRECT COMMUNICATIONS LINK \\ Signed at Washington September 30, 1971 \\ Entered into force September 30, 1971
}

The United States of America and the Union of Soviet Socialist Republics, hereinafter referred to as the Parties,

Noting the positive experience gained in the process of operating the existing Direct Communications Link between the United States of America and the Union of Soviet Socialist Republics, which was established for use in time of emergency pursuant to the Memorandum of Understanding Regarding the Establishment of a Direct Communications Link, signed on June 20, 1963,

Having examined, in a spirit of mutual understanding, matters relating to the improvement and modernization of the Direct Communications Link,

Having agreed as follows:

\section{Article 1}

1. For the purpose of increasing the reliability of the Direct Communications Link, there shall be established and put into operation the following:

(a) two additional circuits between the United States of America and the Union of Soviet Socialist Republics each using a satellite communications system, with each Party selecting a satellite communications system of its own choice,

(b) a system of terminals (more than one) in the territory of each Party for the Direct Communications Link, with the locations and number of terminals in the United States of America to be determined by the United States side, and the locations and number of terminals in the Union of Soviet Socialist Republics to be determined by the Soviet side.

2. Matters relating to the implementation of the aforementioned improvements of the Direct Communications Link are set forth in the Annex which is attached hereto and forms an integral part hereof.

\section{Article 2}

Each Party confirms its intention to take all possible measures to assure the continuous and reliable operation of the communications circuits and the system of terminals of the Direct Communications Link for which it is responsible in accordance with this Agreement and the Annex hereto, as well as to communicate to the head of its Government any messages received via the Direct Communications Link from the head of Government of the other Party.

\section{Article 3}

The Memorandum of Understanding Between the United States of America and the Union of Soviet Socialist Republics Regarding the Establishment of a Direct Communications Link, signed on June 20, 1963, with the Annex thereto, shall remain in force, except to the extent that its provisions are modified by this Agreement and Annex hereto.

\section{Article 4}

The undertakings of the Parties hereunder shall be carried out in accordance with their respective Constitutional processes.

\section{Article 5}

This Agreement, including the Annex hereto, shall enter into force upon signature.

DONE at Washington on September 30, 1971, in two copies, each in the English and Russian languages, both texts being equally authentic.

\author{
FOR THE UNITED STATES OF AMERICA: \\ WILLIAM P. ROGERS
}

FOR THE UNION OF SOVIET SOCIALIST REPUBLICS:

\section{A. GROMYKO}


Missile Control in South Asia and

the Role of Cooperative Monitoring Technology

This page intentionally left blank. 


\title{
APPENDIX I: Annex to the Hot-Line Agreement of 1971
}

\author{
ANNEX TO THE AGREEMENT BETWEEN THE UNITED STATES OF AMERICA AND THE UNION OF SOVIET \\ SOCIALIST REPUBLICS ON MEASURES TO IMPROVE THE U.S.A.-U.S.S.R. DIRECT COMMUNICATIONS LINK
}

Improvements to the U.S.A.-U.S.S.R. Direct Communications Link shall be implemented in accordance with the provisions set forth in this Annex.

\section{CIRCUITS}

(a) Each of the original circuits established pursuant to paragraph 1 of the Annex to the Memorandum of Understanding, dated June 20, 1963, shall continue to be maintained and operated as part of the Direct Communications Link until such time, after the satellite communications circuits provided for herein

become operational, as the agencies designated pursuant to paragraph III (hereinafter referred to as the "designated agencies") mutually agree that such original circuit is no longer necessary. The provisions of paragraph 7 of the Annex to the Memorandum of Understanding, dated June 20,1963, shall continue to govern the allocation of the costs of maintaining and operating such original circuits.

(b) Two additional circuits shall be established using two satellite communications systems. Taking into account paragraph I (e) below, the United States side shall provide one circuit via the Intelsat system and the Soviet side shall provide one circuit via the Molniya II system. The two circuits shall be duplex telephone band-width circuits conforming to CCITT standards, equipped for secondary telegraphic multiplexing. Transmission and reception of messages over the Direct Communications Link shall be effected in accordance with applicable recommendations of international communications regulations, as well as with mutually agreed instructions.

(c) When the reliability of both additional circuits has been established to the mutual satisfaction of the designated agencies, they shall be used as the primary circuits of the Direct Communications Link for transmission and reception of teleprinter messages between the United States and the Soviet Union.

(d) Each satellite communications circuit shall utilize an earth station in the territory of the United States, a communications satellite transponder, and an earth station in the territory of the Soviet Union. Each Party shall be responsible for linking the earth stations in its territory to its own terminals of the Direct Communications Link.

(e) For the circuits specified in paragraph I (b):

- The Soviet side will provide and operate at least one earth station in its territory for the satellite communications circuit in the Intelsat system, and will also arrange for the use of suitable earth station facilities in its territory for the satellite communications circuit in the Molniya II system. The United States side, through a governmental agency or other United States legal entity, will make appropriate arrangements with Intelsat with regard to access for the Soviet

Intelsat earth station to the Intelsat space segment, as well as for the use of the applicable portion of the Intelsat space segment.

- The United States side will provide and operate at least one earth station in its territory for the satellite communications circuit in the Molniya II system, and will also arrange for the use of suitable earth station facilities in its territory for the satellite communications circuit in the Intelsat system.

(f) Each earth station shall conform to the performance specifications and operating procedures at the corresponding satellite communications system and the ratio of antenna gain to the equivalent noise temperature should be no less than 31 decibels. Any deviation from these specifications and procedures which may be required in any unusual situation shall be worked out and mutually agreed upon by the designated agencies of both Parties after consultation.

(g) The operational commissioning dates for the satellite communications circuits based on the Intelsat and Molniya II systems shall be as agreed upon by the designated agencies of the Parties through consultations.

(h) The United States side shall bear the costs of: (1) providing and operating the Molniya II earth station in its territory; (2) the use of the Intelsat earth station in its territory; and (3) the transmission of messages via the Intelsat system. The Soviet side shall bear the costs of: (1) providing and operating the Intelsat earth station in its territory; (2) the use of the Molniya 


\section{Missile Control in South Asia and \\ the Role of Cooperative Monitoring Technology}

II earth station in its territory; and (3) the transmission of messages via the Molniya II system. Payment of the costs of the satellite communications circuits shall be effected without any transfer of payments between the Parties.

(i) Each Party shall be responsible for providing to the other Party notification of any proposed modification or replacement of the communications satellite system containing the circuit provided by it that might require accommodation by earth stations using that system or otherwise affect the maintenance or operation of the Direct Communications Link. Such notification should be given sufficiently in advance to enable the designated agencies to consult and to make, before the modification or replacement is effected, such preparation as may be agreed upon for accommodation by the affected earth stations.

\section{TERMINALS}

(a) Each Party shall establish a system of terminals in its territory for the exchange of messages with the other Party, and shall determine the locations and number of terminals in such a system. Terminals of the Direct Communications Link shall be designated "U.S.A." and "U.S.S.R."

(b) Each Party shall take necessary measures to provide for rapidly switching circuits among terminal points in such a manner that only one terminal location is connected to the circuits at any one time.

(c) Each Party shall use teleprinter equipment from its own sources to equip the additional terminals for the transmission and reception of messages from the United States to the Soviet Union in the English language and from the Soviet Union to the United States in the Russian language.

(d) The terminals of the Direct Communications Link shall be provided with encoding equipment. One-time tape encoding equipment shall be used for transmissions via the Direct Communications Link. A mutually agreed quantity of encoding equipment of a modern and reliable type selected by the United States side, with spares, test equipment, technical literature and operating supplies, shall be furnished by the United States side to the Soviet side against

payment of the cost thereof by the Soviet side; additional spares for the encoding equipment supplied will be furnished as necessary.

(e) Keying tapes shall be supplied in accordance with the provisions set forth in paragraph 4 of the Annex to the Memorandum of Understanding, dated June 20, 1963. Each Party shall be responsible for reproducing and distributing additional keying tapes for its system of terminals and for implementing procedures which ensure that the required synchronization of encoding equipment can be effected from any one terminal at any time.

\section{OTHER MATTERS}

Each Party shall designate the agencies responsible for arrangements regarding the establishment of the additional circuits and the systems of terminals provided for in this Agreement and Annex, for their operation and for their continuity and reliability. These agencies shall, on the basis of direct contacts:

(a) arrange for the exchange of required performance specifications and operating procedures for the earth stations of the communications systems using Intelsat and Molniya II satellites;

(b) arrange for testing, acceptance and commissioning of the satellite circuits and for operation of these circuits after commissioning; and,

(c) decide matters and develop instructions relating to the operation of the secondary teleprinter multiplex system used on the satellite circuits. 


\section{APPENDIX J: Hot-Line Expansion Agreement of 1984}

\section{AGREEMENT BETWEEN THE UNITED STATES OF AMERICA AND THE UNION OF SOVIET SOCIALIST REPUBLICS TO EXPAND THE U.S.-U.S.S.R. DIRECT COMMUNICATIONS LINK}

Signed at Washington July 17, 1984

Entered into force July 17, 1984

The Department of State, referring to the Memorandum of Understanding between the United States of America and the Union of Soviet Socialist Republics regarding the Establishment of a Direct Communications Link, signed June 20, 1963; to the Agreement on Measures to Improve the Direct Communications Link, signed September 30, 1971; and to the exchange of views between the two parties in Moscow and Washington during which it was deemed desirable to arrange for facsimile communication in addition to the current teletype Direct Communications Link, proposes that for this purpose the parties shall:

1. Establish and maintain three transmission links employing INTELSAT and STATSIONAR satellites and cable technology with secure orderwire circuit for operational monitoring. In this regard:

(a) Each party shall provide communications circuits capable of simultaneously transmitting and receiving 4800 bits per second.

(b) Operation of facsimile communication shall begin with the test operation over the INTELSAT satellite channel as soon as development, procurement and delivery of the necessary equipment by the sides are completed.

(c) Facsimile communication via STATSIONAR shall be established after transition of the Direct Communications Link teletype circuit from MOLNIYA to STATSIONAR using mutually agreeable transition procedures and after successful tests of facsimile communication via INTELSAT and cable.

2. Employ agreed-upon information security devices to assure secure transmission of facsimile materials. In this regard:

(a) The information security devices shall consist of microprocessors that will combine the digital facsimile output with buffered random data read from standard 5 inch floppy disks. The American side shall provide a specification describing the key data format and necessary keying material resident on a floppy disk for both parties until such time as the Soviet side develops this capability. Beyond that time, each party shall provide necessary keying material to the other.

(b) The American side shall provide to the Soviet side the floppy disk drives integral to the operation of the microprocessor.

(c) The necessary security devices as well as spare parts for the said equipment shall be provided by the American side to the Soviet side in return for payment of costs thereof by the Soviet side.

3. Establish and maintain at each operating end of the Direct Communications Link facsimile terminals of the same make and model. In this regard:

(a) Each party shall be responsible for the acquisition, installation, operation and maintenance of its own facsimile machines, the related information security devices, and local transmission circuits appropriate to the implementation of this understanding, except as otherwise specified.

(b) A Group III facsimile unit which meets CCITT Recommendations T.4 and T.30 and operates at 4800 bits per second shall be used for this purpose.

(c) The necessary facsimile equipment as well as spare parts for the said equipment shall be provided to the Soviet side by the American side in return for payment of costs thereof by the Soviet side.

4. Establish and maintain secure orderwire communications necessary for coordination of facsimile operation. In this regard:

(a) The orderwire terminals used with the information security devices described in Paragraph 2(a) shall incorporate standard U.S.S.R. Cyrillic and United States Latin keyboards and cathode ray tube displays to permit telegraphic exchange of information between operators. The specific layout of the Cyrillic keyboard shall be as specified by the Soviet side.

(b) To coordinate the work of the facsimile equipment operators, an orderwire shall be configured so as to permit, prior to the transmission and reception of facsimile messages, the exchange of all information pertinent to the coordination of such messages.

(c) Orderwire messages concerning facsimile transmissions shall be encoded using the same information security devices specified in Paragraph 2(a). 


\section{Missile Control in South Asia and the Role of Cooperative Monitoring Technology}

(d) The orderwire shall use the same modem and communications link as used for facsimile transmission.

(e) A printer shall be included to provide a record copy of all information exchanged on the orderwire.

(f) The necessary orderwire equipment as well as spare parts for the said equipment shall be provided by the American side to the Soviet side, in return for payment of costs thereof by the Soviet side.

\section{Ensure the exchange of information necessary for the operation and maintenance of the facsimile system.}

6. Take all possible measures to assure the continuous, secure and reliable operation of the facsimile equipment, information security devices and communications links including orderwire, for which each party is responsible in accordance with this agreement.

The Department of State also proposes that the parties, in consideration of the continuing advances in information and communications technology, conduct reviews as necessary regarding questions concerning improvement of the Direct Communications Link and its technical maintenance.

It is also proposed to note that the Memorandum of Understanding between the United States of America and the Union of Soviet Socialist Republics regarding the Establishment of a Direct Communications Link, signed on June 20, 1963, with the Annex thereto; the Agreement between the United States of America and the Union of the Soviet Socialist Republics on Measures to Improve the Direct Communications Link, with the Annex thereto, signed on

September 30, 1971; those Understandings, with Attached Annexes, reached between the United States and Union of Soviet Republics, Shall constitute an agreement, effective on the date of the Embassy's reply.

Kenneth W. Dean

Department of State,

Washington, July 17, 1984

1 Note: Soviet Charge d' affaires Isakov initialed the Soviet diplomatic note and the notes were exchanged on July 17 , 1984. 


\title{
APPENDIX K: Missile Launch Notification Agreement of 1988
}

\author{
AGREEMENT BETWEEN THE UNITED STATES OF AMERICA AND THE UNION OF SOVIET SOCIALIST \\ REPUBLICS ON NOTIFICATIONS OF LAUNCHES OF INTERCONTINENTAL BALLISTIC MISSILES AND \\ SUBMARINE-LAUNCHED BALLISTIC MISSILES
}

Signed at Moscow May 31, 1988

Entered into Force May 31, 1988

The United States of America and the Union of Soviet Socialist Republics, hereinafter referred to as the Parties,

Affirming their desire to reduce and ultimately eliminate the risk of outbreak of nuclear war, in particular, as a result of misinterpretation, miscalculation, or accident,

Believing that a nuclear war cannot be won and must never be fought,

Believing that agreement on measures for reducing the risk of outbreak of nuclear war serves the interests of strengthening international peace and security,

Reaffirming their obligations under the Agreement on Measures to Reduce the Risk of Outbreak of Nuclear War between the United States of America and the Union of Soviet Socialist Republics of September 30, 1971, the Agreement between the Government of the United States of America and the Government of the Union of Soviet Socialist Republics on the Prevention of Incidents on and over the High Seas of May 25, 1972, and the Agreement between the United States of America and the Union of Soviet Socialist Republics on the Establishment of Nuclear Risk Reduction Centers of September 15,1987 ,

Have agreed as follows:

\section{Article I}

Each Party shall provide the other Party notification, through the Nuclear Risk Reduction Centers of the United States of America and the Union of Soviet Socialist Republics, no less than twenty-four hours in advance, of the planned date, launch area, and area of impact for any launch of a strategic ballistic missile: an intercontinental ballistic missile (hereinafter "ICBM") or a submarine-launched ballistic missile (hereinafter "SLBM").

Article II

A notification of a planned launch of an ICBM or an SLBM shall be valid for four days counting from the launch date indicated in such a notification. In case of postponement of the launch date within the indicated four days, or cancellation of the launch, no notification thereof shall be required.

\section{Article III}

1. For launches of ICBMs or SLBMs from land, the notification shall indicate the area from which the launch is planned to take place.

2. For launches of SLBMs from submarines, the notification shall indicate the general area from which the missile will be launched. Such notification shall indicate either the quadrant within the ocean (that is, the ninety-degree sector encompassing approximately one-fourth of the area of the ocean) or the body of water (for example, sea or bay) from which the launch is planned to take place.

3. For all launches of ICBMs or SLBMs, the notification shall indicate the geographic coordinates of the planned impact area or areas of the reentry vehicles.

Such an area shall be specified either by indicating the geographic coordinates of the boundary points of the area, or by indicating the geographic coordinates of the center of a circle with a radius specified in kilometers or nautical miles. The size of the impact area shall be determined by the notifying Party at its discretion. 


\section{Article IV}

The Parties undertake to hold consultations, as mutually agreed, to consider questions relating to implementation of the provisions of this Agreement, as well as to discuss possible amendments thereto aimed at furthering the implementation of the objectives of this Agreement. Amendments shall enter into force in accordance with procedures to be agreed upon.

\section{Article V}

This Agreement shall not affect the obligations of either Party under other agreements.

\section{Article VI}

This Agreement shall enter into force on the date of its signature.

The duration of this Agreement shall not be limited.

This Agreement may be terminated by either Party upon 12 months written notice to the other Party.

DONE at Moscow on May 31, 1988, in two copies, each in the English and Russian languages, both texts being equally authentic.

FOR THE UNITED STATES OF AMERICA:

George P. Shultz

FOR THE UNION OF SOVIET SOCIALIST REPUBLICS:

Eduard A. Shevardnadze 


\title{
APPENDIX L: Agreement on Nuclear Risk Reduction Centers
}

\author{
AGREEMENT BETWEEN THE UNITED STATES OF AMERICA AND THE UNION OF SOVIET SOCIALIST \\ REPUBLICS ON THE ESTABLISHMENT OF NUCLEAR RISK REDUCTION CENTERS
}

Signed at Washington September 15, 1987

Entered into force September 15, 1987

The United States of America and the Union of Soviet Socialist Republics, hereinafter referred to as the Parties,

Affirming their desire to reduce and ultimately eliminate the risk of outbreak of nuclear war, in particular, as a result of misinterpretation, miscalculation, or accident,

Believing that a nuclear war cannot be won and must never be fought,

Believing that agreement on measures for reducing the risk of outbreak of nuclear war serves the interests of strengthening international peace and security,

Reaffirming their obligations under the Agreement on Measures to Reduce the Risk of Outbreak of Nuclear War between the United States of America and the Union of Soviet Socialist Republics of September 30, 1971, and the Agreement between the Government of the United States of America and the Government of the Union of Soviet Socialist Republics on the Prevention of Incidents on and over the High Seas of May 25, 1972,

Have agreed as follows:

\section{Article 1}

Each Party shall establish, in its capital, a national Nuclear Risk Reduction Center that shall operate on behalf of and under the control of its respective Government.

\section{Article 2}

The Parties shall use the Nuclear Risk Reduction Centers to transmit notifications identified in Protocol I which constitutes an integral part of this Agreement.

In the future, the list of notifications transmitted through the Centers may be altered by agreement between the Parties, as relevant new agreements are reached.

\section{Article 3}

The Parties shall establish a special facsimile communications link between their national Nuclear Risk Reduction Centers in accordance with Protocol II which constitutes an integral part of this Agreement.

\section{Article 4}

The Parties shall staff their national Nuclear Risk Reduction Centers as they deem appropriate, so as to ensure their normal functioning.

\section{Article 5}

The Parties shall hold regular meetings between representatives of the Nuclear Risk Reduction Centers at least once each year to consider matters related to the functioning of such Centers.

Article 6

This Agreement shall not affect the obligations of either Party under other agreements. 
Article 7

This Agreement shall enter into force on the date of its signature.

The duration of this Agreement shall not be limited.

This Agreement may be terminated by either Party upon 12 months written notice to the other Party.

DONE at Washington on September 15, 1987, in two copies, each in the English and Russian languages, both texts being equally authentic.

FOR THE UNITED STATES OF AMERICA:

George P. Shultz

FOR THE UNION OF SOVIET SOCIALIST REPUBLICS:

Eduard A. Shevardnadze 


\section{About the Authors}

Nazir Kamal is a freelance security analyst who previously worked as a Senior Fellow at the Institute of Strategic Studies in Islamabad. He has also worked in other capacities in the past, including Director in the Office of the Advisor to the Prime Minister on Foreign Affairs, and Consultant to the United Nations Department for Disarmament Affairs. He obtained his Ph.D. degree from the Australian National University in Canberra and his Master's degree from the University of Sussex in England, both in the field of International Relations.

Pravin Sawhney is the South Asia Correspondent for Jane's International Defense Review, published by Jane's Information Group, Ltd., Coulsdon, Surrey, CR5 2NX, UK. $\mathrm{He}$ is a former major of the Indian Army (artillery) and has worked with major newspapers in New Delhi as a journalist since 1989. He was the defense editor of The Asian Age based in New Delhi. 
Missile Control in South Asia and

the Role of Cooperative Monitoring Technology

\section{Distribution}

300 MS 1373 CMC Library, 5341

1 MS 9018 Central Tech Files, 8940-2

2 MS 0899 Technical Library, 4916

1 MS 0619 Review \& Approval Desk, 15102 for DOE/OSTI 